\title{
La puerta principal de la aljama almohade de Išbïliya*
}

\section{The Principal Portal of the Išbilliya's Almohad Mosque}

\author{
Alfonso Jiménez Martín \\ Universidad de Sevilla \\ http://orcid.org/0000-0002-9461-1317
}

Este artículo establece las fechas esenciales de la "puerta del Perdón", como acceso principal de la mezquita mayor de Išbīliya, capital europea del imperio almohade. Actualmente es la entrada principal al "patio de los Naranjos" de la catedral de Sevilla (España). Este análisis se basa en las observaciones reunidas durante las obras de restauración que terminaron en 2014. También usamos datos de investigaciones arqueológicas, documentos de varios archivos y la interpretación de las traducciones de las crónicas almohades. Reunimos información literaria y gráfica de todos los elementos islámicos identificados, establecemos hipótesis sobre las disposiciones originales del conjunto y fijamos su cronología en cinco etapas esenciales: construcción de la sala de oración y contorno general del patio (1172-1182), reformas estructurales en el patio en conexión con el inicio de las obras de la torre (11841188), conclusión de la torre y reforma decorativa del edificio, incluyendo las hojas de la Puerta del Perdón (1188-1198), construcción de un mirador mudéjar sobre la Puerta (siglo $\mathrm{XV}$ ) y construcción de un campanario sobre la puerta con su terminación decorativa (15781580).

Palabras clave: Arquitectura almohade; arquitectura mudéjar; mezquita mayor; Išbīliya; catedral; Sevilla.
This paper establishes the essential dates of the "Puerta del Perdón" (Pardon Portal) as the main door of the congregational mosque of Išbilliya, European capital of the Almohad empire. Nowadays it is the main entrance to the "Patio de los Naranjos" ("Cloister of orange trees") of the Seville cathedral. This analysis is based on the observations gathered during the restoration works, ended in 2014. This paper contains archaeological research data, documents from several archives, together with translations of the Almohad chronicles. We collect literary and graphic information about all the Islamic elements identified, establishing hypotheses about the original monument and fixing its chronology in five essential stages: construction of the prayer room and "Patio" general outline (1172-1182), structural reforms in the courtyard related with the begin of Giralda minaret (1184-1188), completion of the minaret and decorative reform of the building, including the bronze doors of the "Puerta" (1188-1198), construction of a Moorish balcony over the Gate (1433-1496 century) and finally construction of a bell gable and its decorative completion (1578-1580).

Key words: Almohad architecture; main mosque; Išbīliya; Seville; Cathedral; Moorish architecture.

* Trabajo desarrollado en el proyecto HAR2014-53006-P, “Arquitectura Sa'adí. La pervivencia de al-Andalus en el Magreb (ARSA)" (Ministerio de Economía y Competitividad, Programa Estatal de Fomento de la Investigación Científica y Técnica de Excelencia).

Copyright: (C) 2017 CSIC. Este es un artículo de acceso abierto distribuido bajo los términos de la licencia de uso y distribución Creative Commons Attribution (CC-by) España 3.0. 
Los sevillanos creen que la puerta principal del claustro de la catedral de Sevilla se llama "del Perdón" por el Ecce Homo que, en un pequeño retablo del XVIII, vemos en el rincón nororiental de su zaguán ${ }^{1}$. Si el nombre cristiano de la puerta principal de la antigua aljama se debiera a las imágenes, también podría ser la "puerta de la Cogolla", por el cuadro de san Millán que hay en ella desde $1724^{2}$, o la "puerta de San Ivo", pues en el siglo XV el canónigo Johan Sánchez estaba enterrado ante su altar ${ }^{3}$, que era el más cercano. Pero lo cierto es que se llama así desde antes, por lo menos desde el 3 de mayo de $1363^{4}$. Por tanto, al Ecce Homo de la Humildad y Paciencia se llama "Cristo del Perdón" porque está en la puerta de ese nombre y no al revés, pues no es una cuestión de devociones sino de liturgia medieval: se otorgaba a la principal por su papel en la reconciliación pública de penitentes del jueves santo ${ }^{5}$. Por ello, al proyectar la catedral gótica, también se llamó así la actual de la Asunción, como acredita la copia de la traza conservada en Bidaurreta ${ }^{6}$; así es que, durante dos siglos, tuvo sendas puertas del Perdón, la nueva, que era gótica, y otra almohade, la vieja, resultado de una serie de obras cuya cronología pretendo aclarar ${ }^{7}$, partiendo de la crónica de 'Abd al-Malik b. Muhammad Ibn Șāhị al-Ṣalāt':

A. 1168-9. Comenzó el califa Abū Ya'qūb Yūsuf la ordenación del sector meridional de Išbīliya mediante recintos militares intercalados entre la saturada medina, la alcazaba del siglo XI, la ampliación almorávide y los ríos.

\footnotetext{
${ }^{1}$ A.C.S., 1707,68 y $68 \mathrm{v}^{\mathrm{o}}$ "presentó una indulgencia traída por un devoto para quien resase a el Santo Ecce Homo que esta en la puerta del perdón [...]”, Sebastián de Santa María, que testó el 17 de agosto de 1723, mencionando el "primoroso retablo de piedra q a sus expensas a hecho para el Ssmo Christo de la humildad y Pasiencia" (Quiles García, Teatro de la Gloria, p. 297, n. 1450).

${ }^{2}$ Gestoso y Pérez, Sevilla Monumental, p. 95.

${ }^{3}$ A.C.S., 1411, XLV, 275.

${ }^{4}$ Dotación del sepulcro de Nicolás Rodríguez en la claustra de San Esteban, cerca de la puerta del Perdón, según A.C.S., 1363.

${ }^{5}$ Laguna Paúl, "Marco arquitectónico", pp. 32-33.

${ }^{6}$ Alonso Ruiz y Jiménez Martín, La traça, p. 22.

${ }^{7}$ Los datos proceden de las obras que he dirigido entre 1979 y 2014. Agradezco a doña Isabel González Ferrín, don Antonio Almagro Gorbea, don Álvaro Jiménez Sancho y don José Miguel Puerta Vílchez sus valiosas aportaciones.

${ }^{8}$ Son fáciles de consultar las traducciones de Martínez Antuña, Sevilla; Huici Miranda (Ibn Șāhib al-Șalāt, al-Mann) y Roldán Castro, "De nuevo sobre la mezquita”, que difieren en matices.
} 
B. Abril-mayo de 1172. El "príncipe de los alarifes", Ahmad Ibn Bāsu, tras la compra de fincas, explanación y replanteo, comenzó las obras, que siguieron hasta el 27 de febrero de 1176.

C. 30 de abril de 1182. Fue obligatorio el uso del oratorio sin que el alminar estuviera iniciado ni, en apariencia, resuelto su entorno inmediato, ya que no consta la existencia del patio.

D. 26 de mayo de 1184. El califa decidió incluir la aljama en una extensión de la alcazaba, adosando el alminar al ángulo suroriental de la sala, donde convergerían las murallas; estas obras se detuvieron a su muerte, en julio; su sucesor, Abū Yūsuf al-Manșūr, prosiguió la torre, pero modificó el trazado de los muros para que la mezquita quedase adyacente a la alcazaba pero integrada en la medina ${ }^{9}$. Poco después las obras se pararon.

E. Entonces construirían la $m \bar{\imath} d \bar{a}^{10}$, adosada al exterior de una de las nuevas murallas, la que tocaba en la torre, por donde discurría su acometida de agua.

F. 1188-9. Se ordenó a 'Alī al-Gumārī continuar la torre, que además reedificó lo arruinado en el oratorio, quizás los muros derruidos para cimentar el alminar ${ }^{11}$; además hizo ventanas acristaladas y solerías, interiores y exteriores.

G. 9 de febrero de 1196. Empezaron los derribos y “ordenó que se ampliara la explanada de la mezquita, donde rezaba la gente cuando se hacía preciso" "12, labrando la Alcaicería frente a la puerta del Perdón;

\footnotetext{
${ }^{9}$ Las excavaciones muestran que se hizo, al menos en parte; sólo usaré los datos emergentes.

${ }^{10}$ Vera Reina, "La mida".

${ }^{11}$ Ibn Șāḥib al-Ṣalā, al-Mann, p. 201 "le mandó reanudar la construcción del alminar citado y reedificar lo que se había arruinado en la mezquita [...] y reparó lo que se había arruinado en las tres naves de la mezquita por el lado de Levante y por el de Poniente y el Norte, y lo consolidó, y fortificó la obra"; Roldán Castro, "De nuevo sobre la mezquita", p. 20 "había ordenado que se reanudasen las obras del alminar y se reparase cualquier deterioro [localizado] en la aljama [...] y restauró lo que se había deteriorado en tres naves de la mezquita, la del este, la del oeste y la del norte, las reparó y las reforzó".

${ }^{12}$ Roldán Castro, "De nuevo sobre la mezquita", p. 21, quizá la explanada fuera la citada el 26 de mayo de 1184 cuando el califa mandó "construir una sólida muralla en la alcazaba de la ciudad que arrancara en el comienzo de la edificación y pasara por delante de la explanada de Ibn Jaldún, en el interior de Sevilla, y que construyera un alminar a la mezquita aljama". Huici ofrece una traducción ligeramente distinta "ensanchar el patio de la mezquita, donde rezaba la gente cuando se veía forzada a ello" (Ibn Șāhịib al-Ṣalāt, alMann, p. 203) que denota la ampliación del șaḥn, del cual no había noticias previas.
} 
por tanto, la aljama ya tenía, por el norte, la extensión y acceso histó$\operatorname{ricos}^{13}$.

H. 1198. Otro cronista, 'Alī b. Abī Zar', indica que el califa mandó rematar el alminar mediante el yāmūr que hizo Abū 1-Layt al-Siqî1līîn; según Ibn Șāhib al-Ṣalāt esto ocurrió el 19 de marzo de $1198^{15}$.

El complejo tenía $34.000 \mathrm{~m}^{2}$ [Figura 1], incluyendo la Alcaicería, el pabellón de abluciones, el alminar y los "corrales" amurallados que,

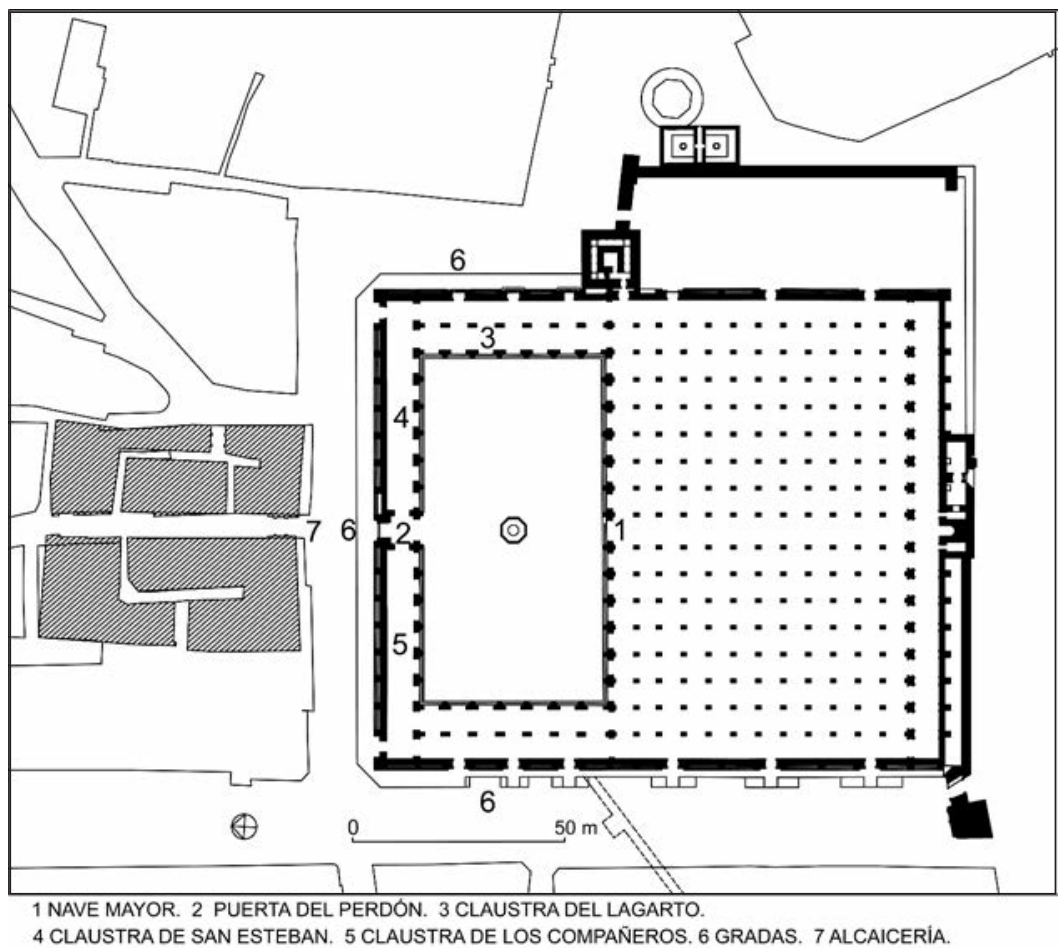

Figura 1. Planta del conjunto de la aljama con los datos reunidos hasta 2014; destaca la sala de oración, con la qibla a la derecha, el alminar ubicado arriba en el centro cerca del pabellón de abluciones; la parte sur está rodeada por los "corrales" que amurallaban el oratorio (Datos y dibujo del autor).

${ }^{13}$ El 26 de diciembre de 1253 existía "una tienda en Seuilla que se tiene con la iglesia de sancta maría la mayor, e esta tienda es la primera que se tiene con la puerta por que ome entra ala Eglesia de parte del Alcaiçería, ala mano siniestra" (Ballesteros Beretta, Sevilla, LXII y LXIII), es decir, la puerta que en 1363 se llamó “del Perdón”.

${ }^{14}$ Ibn Abī Zar', Rawd al-Qirțās, p. 447.

${ }^{15}$ Ibn Șāḥib al-Ṣalāt, al-Mann, p. 202. 
desde 1248, formaron parte del conjunto; $14.432 \mathrm{~m}^{2}$ correspondían al oratorio, cuya orientación sur era la típica local y una chocante tendencia almohade ${ }^{16}$. Hasta 1248, cuando fue convertido en templo, no tenemos otras noticias ni constan detalles de su cristianización, aunque la anómala qibla facilitó el proceso; tras cerrar la mayoría de los arcos de la sala al patio, sufrió un complejo y prolongado repartimiento, manteniéndose el șaḥn como claustro, con capillas en sus costados de levante y poniente. El uso funerario empezaría pronto, pues en $1252^{17} \mathrm{el}$ rey Fernando fue enterrado en la nave mayor y ya en 1266 había una tumba en la claustra del Lagarto; en 1283 se instaló una capilla familiar, la de San Esteban, en el mejor sitio del patio ${ }^{18}$, el rincón nororiental de la galería de levante, y por ello el espacio libre hasta la puerta del Perdón fue la clastra de Sant Esteuan; en el rincón opuesto se dotó en 1328 la capilla del Ihesu y su nave fue la de los companneros ${ }^{19}$.

El "Libro Blanco"20, empezado en 1411, acredita el final del loteo funerario y cómo parte de las naves del "corral de los naranjos", así llamado en $1421^{21}$, aún estaban expeditas; pero no fue por mucho tiempo, pues en 1433 empezó el derribo de la antigua sala de oración, por lo que muchas actividades alojadas en ella pasaron al patio; así en 1438 los derribos ${ }^{22}$ afectaban a la librería y a la capilla del Sagrario, dedicada a San Clemente, de modo que, tras algunas peripecias, pues quizás hubiese una precaria mudanza inicial, fue instalada en la de San Esteban, mientras el contenido de la Real, que también fue derribada, pasó a un doblado de la nave del Lagarto 23 ; así estaban en 1480, según el relato de un robo que afectó al tesoro, que estaba custodiado en el

${ }^{16}$ Jiménez Martín, "La qibla”, p. 196.

${ }^{17}$ Jiménez Martín, "Las fechas", pp. 22-31.

${ }^{18}$ Ortiz de Zúñiga, Annales 2, p. 283. Tenía como ventajas la orientación, el muro oriental disponible para instalar su presbiterio particular, el arco occidental usado como portada y la nave expedita; los ámbitos contiguos se repartieron antes de 1333 .

${ }^{19}$ Según A.C.S., 1439 tenía el cabildo 79 miembros: nueve "dignidades", 32 canónigos, 19 racioneros y finalmente 20 "compañeros".

${ }^{20}$ Jiménez Martín y Pérez Peñaranda, Cartografia, pp. 125 y ss y Pérez-Embid Wamba, Culto funerario.

${ }^{21}$ Jiménez Martín y Pérez Peñaranda, Cartografia, p. 131.

22 Jiménez Martín, Anatomía, p. 231.

${ }^{23}$ Hicieron una entreplanta sobre cuatro capillas familiares, a la que se accedía, hasta 1992, por una escalera, heredera de la del XV, que partía del extremo norte de la galería del Lagarto. 
desván funerario ${ }^{24}$. En $1543^{25}$ la capilla de San Esteban y San Clemente, acrecentada con funciones parroquiales y expandida por su clastra hasta la puerta del Perdón, se convirtió en Capilla Real, ya que bajaron hasta su presbiterio los cuerpos reales, pues estaban "[...] depositados en sierto lugar [el doblado] de esa iglesia, que no es dezente para ello"26. Liberado el desván lo ocupó la biblioteca ${ }^{27}$ y así permaneció todo hasta que en 1579 se inauguró el actual panteón regio ${ }^{28}$, aunque continuaron las funciones parroquiales del "Sagrario Viejo" un siglo más; el nuevo, último en la historia del templo, empezó en 1618 con el derribo de las dos naves occidentales del patio para construir el templo barroco de San Clemente, inaugurado en $1662^{29}$; entonces el antiguo, que estaba abovedado ${ }^{30}$ y tenía dos plantas, se convirtió en almacenes, librerías, oficinas y viviendas ${ }^{31}$. La nave de los Compañeros estuvo expedita hasta que en $1657^{32}$ se dedicó a sacristía del nuevo Sagrario, abovedada a media altura para obtener un desván. La apariencia actual del conjunto es la que, en general, produjeron las obras del arquitecto Félix Hernández Giménez, concluidas en $1972^{33}$.

Tantos cambios han dejado numerosos rastros, cuya existencia pasa inadvertida a turistas, eruditos y transeúntes poco avisados, por lo que es conveniente describir sistemáticamente las formas, ayudados por las fotografías y dibujos adjuntos.

En la puerta [Figura 2] podemos distinguir seis zonas sucesivas y superpuestas: dos portadas, la de las Gradas al norte y la del Patio al sur, el zaguán que hay entre ellas, la azotea que lo cubre, la espadaña sobre la portada del norte, y la tribuna o mirador sobre la meridiona ${ }^{34}$. Las portadas son parecidas, cada una con un arco de herradura centrado entre estribos, pero con una significativa diferencia de tamaño, pues la exterior tiene 3,52 $\mathrm{m}$ de luz libre, con 7,84 $\mathrm{m}$ de estribo a estribo, que

\footnotetext{
${ }^{24}$ Kirschberg Schenck, Catálogo, pp. 532-533. También guardaba el pendón de Sevilla (Collantes de Terán Sánchez, "De nuevo, sobre el pendón real").

${ }^{25}$ González de León, Noticia artística histórica, p. 312.

${ }^{26}$ Gestoso y Pérez, Sevilla Monumental, p. 302.

${ }^{27}$ Ocupaba desde 1496 parte del patio (Âlvarez Márquez, El mundo del libro, p. 24).

${ }^{28}$ de Sigüenza Esteban, Traslacion de la imagen, p. 124.

${ }^{29}$ Bravo Bernal, El Sagrario, p. 125.

${ }^{30}$ Falcón Márquez, La capilla, pp. 40 y 61.

${ }^{31}$ Luna Fernández-Aramburu y Serrano Barberán, Planos y dibujos, p. $155 \mathrm{~s}$.

${ }^{32}$ Bravo Bernal, El Sagrario, p. 117.

${ }^{33}$ Gómez de Terreros y Guardiola y Díaz Zamorano, "La restauración".

${ }^{34}$ Formas y medidas en Almagro Gorbea et al., Atlas arquitectónico, disponible, de forma gratuita y universal, en http://hdl.handle.net/10261/20324.
} 


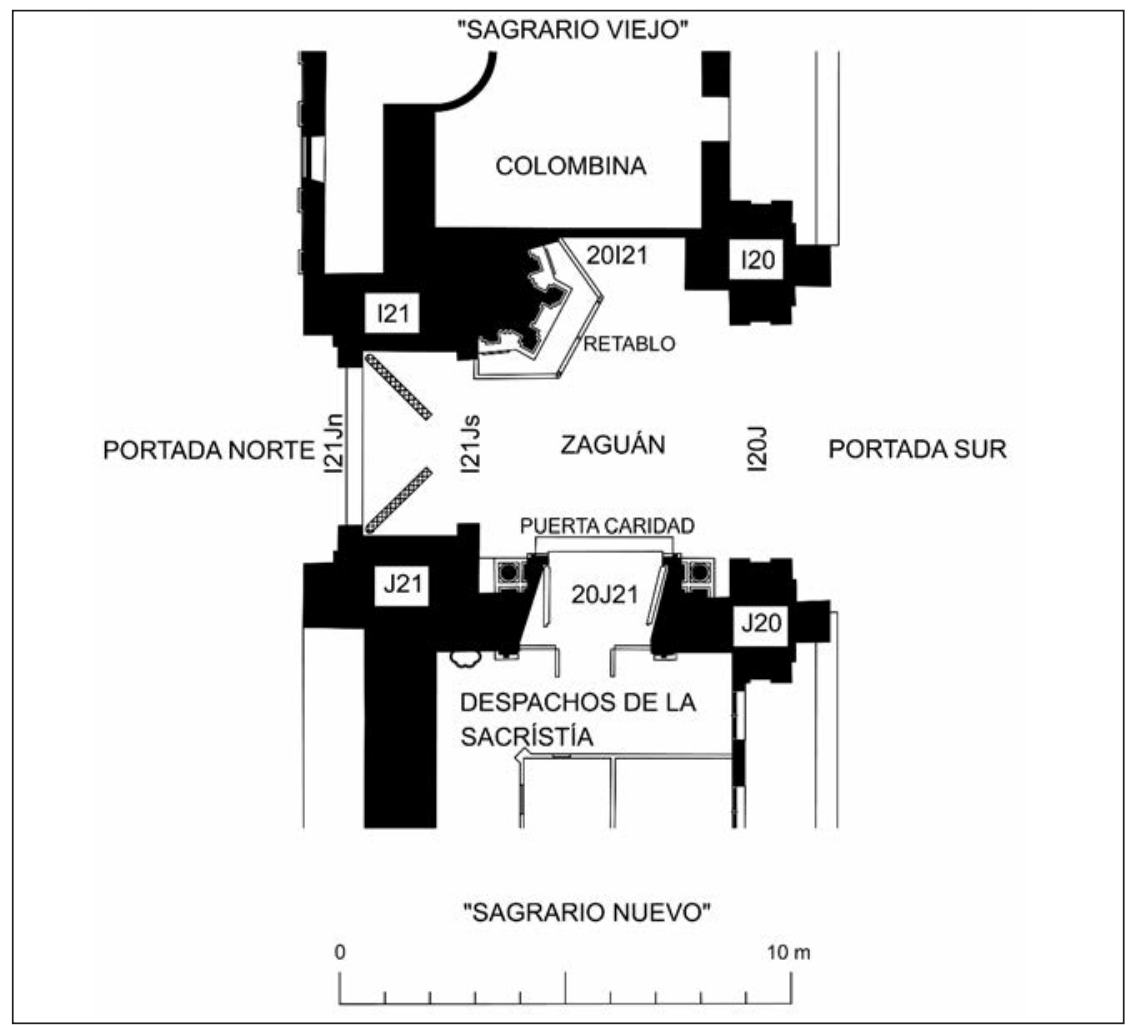

Figura 2. Planta esquemática de la puerta del Perdón en la actualidad, con la denominación convencional de los elementos descritos y las signaturas de soportes y arcos basadas en las alineaciones generales del edificio musulmán (Datos y dibujo del autor).

en la interior son 5,19 y 8,77 respectivamente. La externa está flanqueada por las dos plantas de la Biblioteca Capitular, a levante, y los de las dependencias del Sagrario actual, a poniente, cuyos tejados son más bajos que la puerta. Su acceso ${ }^{35}$ está en la cota $+9,60$ m.s.n.m., $10 \mathrm{~cm}$ sobre el pavimento de las Gradas y 16 sobre el del zaguán, descendiendo el suelo hasta $+9,31$ en el patio, cotas que no deben ser muy distintas de las musulmanas ${ }^{36}$.

${ }^{35}$ Debe ser, en parte, "el batidero baxo todo de vna pieça de hermofo Marmol de manchas verdes, y blancas" (de Morgado, Historia de Sevilla, p. 96).

${ }^{36}$ El pavimento almohade de las Gradas está unos $50 \mathrm{~cm}$ bajo el actual, cfr. Tabales Rodríguez et al., "Investigaciones arqueológicas", p. 154 s. 
La base estructural y formal de la puerta almohade la constituyen el muro exterior y los dos pilares del patio, con los cinco arcos y las dos bóvedas que los enlazan. El muro, que materializa la alineación septentrional del edificio ${ }^{37}$, es de tapia, con 1,44 m de espesor, conservando su altura de $12,11 \mathrm{~m}$, incluidos tres merlones de grada originales ${ }^{38}$; en los puntos donde se cruza con las alineaciones "I" y "J", vemos, con su zócalo pétreo, los estribos de la portada exterior, cuyas jarjas de ladrillos encajonan las tapias; sus responsiones en el patio son los pilares cruciformes "I20" y "J20", con estribos y arcos duplicados al estilo cordobés. Habida cuenta de la ubicación, dimensiones y funcionalidad de la puerta sus constructores complementaron esta estructura general, formada por un muro y dos pilares exentos, mediante tres soportes más a cada lado; los mayores son los muros de ladrillo que prolongan los pilares "I20" y "J20" hasta llegar al de tapial de la alineación " 21 ", formando el zaguán, que se comunicaba con las clastras gracias a los arcos "20I21" y "20J21"39; los pequeños son las jambas y mochetas de la puerta, arrimadas a la alienación " 21 ". De esta manera, al ingresar en el edificio, vemos el arco exterior "I21Jn", a continuación el "I21Js", que delimita el espacio para las hojas, y al fondo, saliendo al patio, se perfila el "I20J", que enlaza los pilares citados, quedando a los lados los otros, de los que sólo es visible el "20I21"; todos son de herradura túmida y arrancan de la misma cota, marcando un plano horizontal del que surgen las yeserías decorativas; aumentan sus luces de norte a sur, pues tienen 3,52 m, 3,79 y 5,19 m respectivamente, mientras los laterales miden 3,50; del aparejo del arco "I21Jn" no sabemos nada, aunque, como los otros tres, debe ser de ladrillo, trazado a partir de cuatro centros y con juntas que convergen en la línea de los arranques; se observa que la rosca del arco "I21 Js" tiene dos pies de espesor, la de "20I21" dos y medio y la de "I20J" tres; todos llevaron alfices, aunque el de la cara norte del arco "I20J" ha sido eliminado.

\footnotetext{
${ }^{37}$ Usaré el sistema propuesto por Ch. Ewert (Jiménez Martín y Pérez Peñaranda, Cartografia, pp. 14 y 15$)$.

${ }^{38}$ Descubiertos en 2013; la potencia del muro explica que en 1441 "hasta las mismas torres del sagrario de la Santa Iglesia sirvieron de castillo [...]" (Ortiz de Zúñiga, Annales 3 , p. 25).

${ }^{39}$ El arco "20I21" daba paso en 1411 a la nave de San Esteban; el "20J21", que accedía a la de los Compañeros, fue colmatado en el XVII por la portada de la Caridad (Bravo Bernal, El Sagrario, pp. 117 y ss).
} 


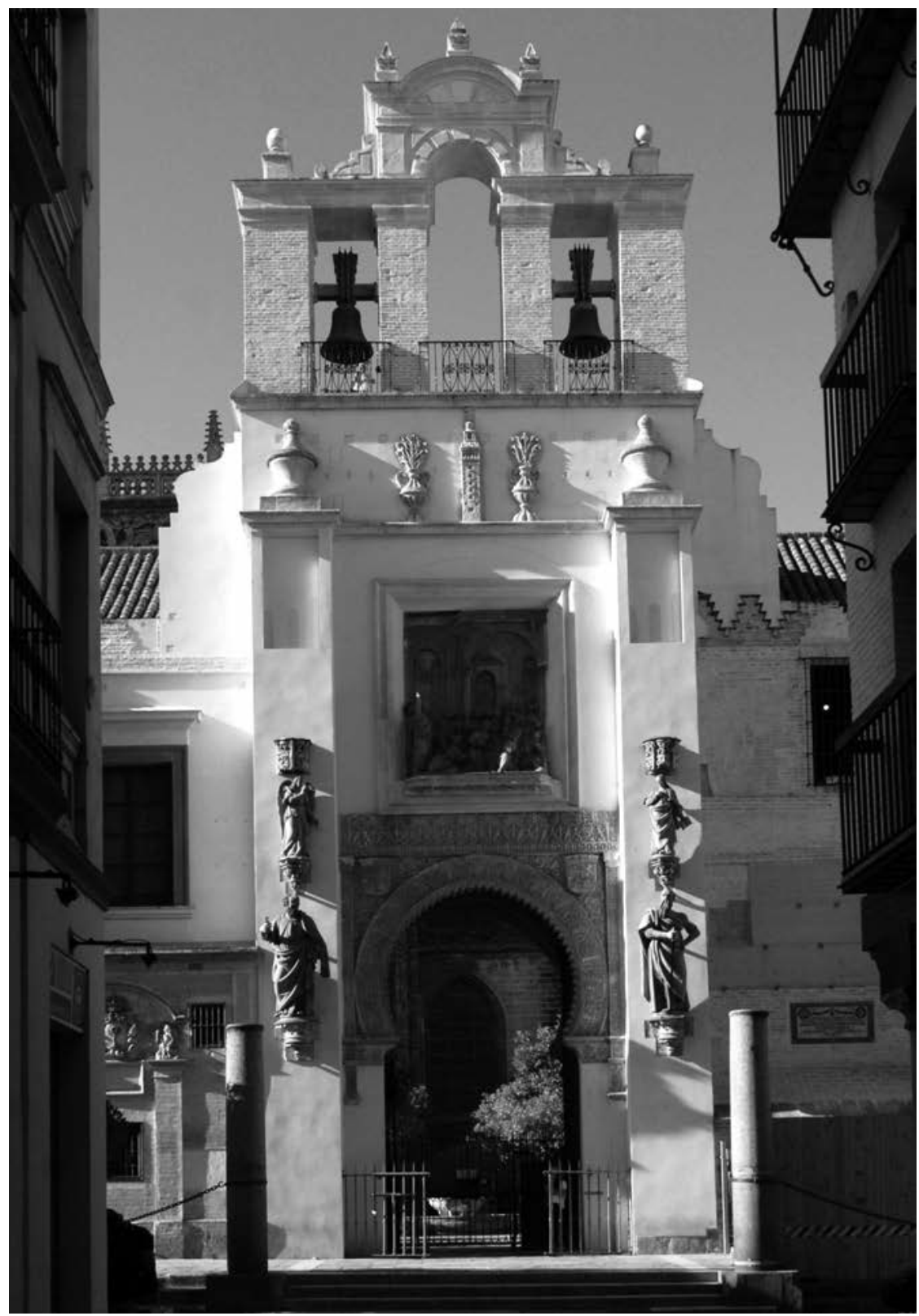

Figura 3. La portada norte de la puerta del Perdón desde la calle Hernando Colón, eje norte-sur de la Alcaicería, tras la restauración de 2014, apreciándose, a la derecha, el muro de tapial y los tres merlones de grada recuperados durante las obras (Foto del autor).

Al-Qanțara XXXVIII 2, 2017, pp. 287-332 ISSN 0211-3589 doi: 10.3989/alqantara.2017.010 
La portada exterior [Figura 3] la forman los dos estribos ("I21" y "J21") y el arco "I21Jn", sobre el que vemos el relieve de la "Expulsión de los mercaderes del templo", su arco de descarga, el emblema capitular entre cornisas y finalmente la espadaña. En el estribo de levante tenemos una repisa tardogótica de alabastro, con vegetación y plumas, que sostiene una estatua de san Pedro; más arriba, sobre una ménsula menor, vemos el arcángel Gabriel, protegido por un dosel gótico de dos frentes curvos; finalmente hay un cajeado rectangular que casi agota el espacio frontal ${ }^{40}$. El estribo de poniente también presenta una repisa, sostenida por una mano que sale de la pared, portando a san Pablo; sobre él, en una ménsula como la simétrica, tenemos una imagen de María en la Anunciación, con su dosel gótico de tres frentes; las cuatro estatuas y el relieve son de terracota; la parte alta está igualmente cajeada.

El arco "I21Jn" está cubierto por menudas yeserías de poca calidad material, como denuncia el deterioro de los relieves y las reparaciones antiguas; su diseño, que incluye el escudo de Castilla y León y roleos y grutescos, no es cuidadoso, pues los módulos del intradós no alcanzan la clave al unísono; sobre la rosca existe un friso enmarcado por tres lados, pero no por arriba, pues los temas decorativos quedan cortados en la base del relieve, sugiriendo que esta yesería seguía hacia arriba. Los estribos concluyen en la primera cornisa pétrea, de perfil clásico, que se repite más arriba al arrancar la serliana de la espadaña, formada por cuatro pilares, dinteles, arco, arquitrabes, pilastras y remates ${ }^{41}$; completan el conjunto dos aletas recortadas que descargan sobre el almenado general; rematando cada estribo, vemos una eolípila pétrea en forma de incensario, el emblema capitular (la Giralda entre jarrones con lirios) y cuatro filas de mechinales, estratificados y simétricos, marcados en el enlucido actual, que son las huellas de un tejaroz renacentista.

La primera obra cristiana de esta portada la menciona Ortiz de Zúñiga ${ }^{42}$ pues, tras la victoria del Salado de 1340, "Dióla el Rey [Alfonso XI, a la catedral] algunas preseas del despojo, y fabricó y adornó suntuosamente la puerta que llaman del Perdón del patio de los naranjos,

${ }^{40}$ Hasta 2013 el estribo estaba enfoscado con cemento, ocultando un relleno de ladrillo que a su vez enrasaba las huellas de un primer tejaroz, el almohade exterior.

${ }^{41}$ Tiene antepechos de hierro forjado y dos campanas, la mayor de 1778.

${ }^{42}$ Ortiz de Zúñiga, Annales 2, p. 105. 
sobre que se ven las armas de Castilla y León entre bellísimos follages [...]"; debemos rechazar este dato en su tenor literal, pues las yeserías actuales no pueden ser del XIV ${ }^{43}$. Unos documentos de $1498^{44}$ mencionan unas pinturas abonadas a Gonzalo Díaz, los arreglos que Antón Pérez hizo a esculturas y relieves y la reparación de yeserías que cobró Diego Fernández ${ }^{45}$, por lo tanto, antes de 1498 existía una maltrecha y compleja decoración que, al menos en parte, era cristiana. Gestoso y Pérez ${ }^{46}$ explicó que "las yeserías platerescas que al presente se conservan [...] dice Ceán que fueron encargadas por el Cabildo á Bartolomé López en 1519. En el libro de Fábrica de 1522 consta que á aquél se le dieron '4200 mrs. que Diego Rodriguez e Juan Rodriguez albañiles juzgaron que merecían las demasías que hiso en la yesería de la puerta del perdón""47, añadiendo que "No se le pagaron más que 1875 [mrs] por las demasías de la yesería 'e de lo que perdió e le costó toda la obra de la puerta del perdón"”; por tanto cabe sostener que las yeserías actuales las hizo Bartolomé López en 1519 para sustituir las adobadas en 1498, como parte de una obra que incluyó las terracotas mencionadas, obras de Miguel Perrín hechas entre 1519 y $1522^{48}$.

En 1578 completaron la puerta, en su papel de zaguán de la parroquia $^{49}$, con un campanario en forma de espadaña, terminado en noviembre de 1580 e hicieron el segundo tejaroz y arreglaron las yeserías, el

${ }^{43}$ Habida cuenta de la semejanza de esta portada con la homónima de Córdoba, decorada en 1377 y cuyas hojas son copias de las de Sevilla, supongo que Ortiz de Zúñiga extrapoló los datos (Nieto Cumplido, La Catedral, p. 606-610 y Jordano Barbudo, "La puerta"). En la "Gran Crónica de Alfonso XI", salvo la reseña de la entrada triunfal en la catedral, no hay más.

${ }^{44}$ Gestoso y Pérez, Sevilla Monumental, p. 90.

${ }^{45}$ A.C.S., 1498: 15, entonces solaron las Gradas (A.C.S., 1498: 15, 22-1v $v^{0}, 27-2,35-$ $\left.1 \mathrm{v}^{\mathrm{o}} \mathrm{y} 45\right)$.

${ }^{46}$ Gestoso y Pérez, Sevilla Monumental, p. 86.

${ }^{47}$ A.C.S., $1522: 48 v^{\circ}$ y 50.

${ }^{48}$ Laguna Paúl, "Miguel Perrin en las portadas", pp. 738-739, menciona sus trabajos en 1519, 1520 y 1521; Laguna Paúl, "Miguel Perrín, imaginero", p. 91, escribió "Desconocemos quién fue el autor conceptual del proyecto iconográfico de esta Puerta del Perdón 'Vieja', que evidentemente dirigió el aparejador Gonzalo de Rozas desde 1519", aunque "la instalación se demoró hasta el verano de 1522"; Laguna Paúl, "Llegada y primeras", pp. 146 y 151, fija 1519 para las imágenes mayores y que usó cierto taller "[...] desde 1519 hasta que en 1524 y después cambió su domicilio a unas casas situadas junto al postigo de la Antigua. En este primer taller del corral modeló y coció las imágenes y el relieve de la puerta del Perdón "vieja"”.

${ }^{49}$ En 1502 el Sagrario Viejo focalizaba las propiedades de la Fábrica en la calle Alemanes (A.C.S., 1542, 114-125). 
relieve y los demás elementos figurativos ${ }^{50}$; en 1638 se aderezó el guardapolvo ${ }^{51}$, intervención que entre 1678 y 1681 repitió Esteban García tras reparar "la muralla de la Yglesia, desde la puerta de la Granada hasta la puerta del Perdón, por la vanda de afuera [...]"52; en 1714, cuando volvieron a pavimentar las Gradas ${ }^{53}$, repararon los adornos y las estatuas ${ }^{54}$ y nuevamente se restauró todo en $1743^{55}$. Cuatro imágenes informan de su apariencia, empezando por un cuadro de $1662^{56}$, que muestra el tejaroz, cuyas formas clásicas casan bien con las cuatro tandas de mechinales; también tenemos como referencia visual una pintura de Martínez de $1747^{57}$, así como una imagen de Tortolero, de $1748^{58}$, que representan el tejaroz y las pinturas. Finalmente aparecen estos elementos en un grabado de la guía de Ceán ${ }^{59}$, pero pronto se perdieron varios, pues el 21 de enero de 1818 “[...] se acordó no se quite el filigranado de la Puerta del Perdón que guarnece el medallón que hay sobre ella y se aprobó haberse quitado el de las columnas de los lados que manifestaron los señores de fabrica estarse cayendo y no haber en esta ciudad quien lo pueda componer" 60 ; por ello el grabado de Finden de 1834, sobre dibujo de Blanchard ${ }^{61}$, muestra muy disminuidas las yeserías respecto a 1747; en 1838 parece que fue derribado el guardapolvo ${ }^{62}$, sustituido por el emblema capitular y las eolípilas,

\footnotetext{
${ }^{50}$ Recio Mir, "La reforma”, p. 76, eran cuatro imágenes femeninas, situadas en lo alto de los estribos, alojadas en los cajeados.

${ }^{51}$ Gestoso y Pérez, Sevilla Monumental, p. 92.

${ }^{52}$ Quiles García, Teatro de la Gloria, p. 84 y Cruz Isidoro, Arquitectura sevillana, p. 117.

${ }^{53}$ A.C.S., $1498-1525: 221^{\circ}$, con noticias de 1498 y 1665.

${ }^{54}$ Gestoso y Pérez, Sevilla Monumental, p. 89.

${ }^{55}$ Según Sandier (Gestoso y Pérez, Sevilla Monumental, pp. 91 y 92) y A.C.S., 17011719,204

${ }^{56}$ Falcón Márquez, "Procesión con motivo"; lo reprodujeron Serrera Contreras, Oliver Carlos y Portús Pérez, Iconografía de Sevilla, p. 267.

${ }^{57}$ Serrera Contreras, Oliver Carlos y Portús Pérez, Iconografía de Sevilla, p. 237.

${ }^{58}$ Serrera Contreras, Oliver Carlos y Portús Pérez, Iconografía de Sevilla, p. 276.

${ }^{59}$ Ceán Bermúdez, Apéndice.

${ }^{60}$ A.C.S., 1818, 13v; Gestoso y Pérez, Sevilla Monumental, pp. 89, 91, 92 y 95, atestigua más reparaciones.

${ }^{61}$ Recio Mir, "La reforma", pp. 84, 85 y 87. Lo reproduce Calvo Serraller et al., Iconografia de Sevilla, p. 322.

${ }^{62}$ Recio Mir, "La reforma", p. 75. Amador de los Ríos y Serrano, Sevilla pintoresca, p. 184, publicó que el "mayordomo Campos" había ordenado el derribo, pero entre 1796 y 1850 no hubo ningún capitular así apellidado (A.C.S., 1796-1850); en los autos capitulares de este año y en el libro de la Diputación de Negocios de 1833 a 1856 tampoco hemos encontrado algo que concierna al tema.
} 
como los litografió entonces Casajús ${ }^{63}$; al poco cayeron otras partes ${ }^{64}$ hasta quedar lo fotografiado por Leygonier en $1843^{65}$.

Antes de dejar el exterior conviene datar otros añadidos modernos, localizados desde la puerta del Perdón hacia levante, en forma de retablos y capillas exteriores del Sagrario Viejo que ocultaron el muro almohade. El más antiguo es de 1563, cuando Luis de Vargas pintó al fresco, sobre la puerta actual de la Biblioteca Colombina ${ }^{66}$, un "Cristo camino del Calvario"67; en 1616 pintaron una Inmaculada frente a la esquina de la Alcaicería ${ }^{68}$, cuyo retablo se terminó en $1701^{69}$; bajo ella, en 1706, se instaló una Asunción, con altar desde $1723^{70}$; en $1732^{71}$, la hermandad del Rosario de la Antigua ocupó el citado acceso de la Biblioteca Colombina y la puerta por la que se avisaba para administrar los sacramentos se hizo quizás a fines del XVII; los espacios que hoy albergan instalaciones, a los lados de la capillita de la Asunción, ya aparecen en el citado libro de Ceán de 1805.

Pasemos al zaguán de la puerta del Perdón. Los arcos "I21Jn" y "I21Js" [Figura 4] delimitan un espacio rectangular de proporción dupla, correspondiente al giro de las hojas, cada una de las cuales, con 7,24 m de alto, 1,95 de ancho y 0,18 de espesor, está armada por medio de dos largueros, quince peinazos y una docena de tablas, todo de cedro del Atlas ${ }^{72}$. A pesar de encajar y entablar con poca holgura, son manejables, pues giran en los largueros, abajo mediante chumaceras metálicas nuevas y arriba en las antiguas ranguas del dintel, adosado al arco

${ }^{63}$ Yáñez Polo, V.M. Casajus, p. 16.

${ }^{64}$ Recio Mir, "La reforma", p. 75. En los autos capitulares coetáneos no encuentro nada, pero Velázquez y Sánchez, Anales, p. 502, asegura que el 8 de agosto de 1839 cayó "el moldurón de cantería [no el tejaroz] del cuadro en relieve".

${ }^{65}$ Reproducen la imagen Yáñez Polo y Mesa García, Sevilla recuperada, p. 21.

${ }^{66}$ Menciona esta puerta, reabierta en 1990, Ortiz de Zúñiga, Annales 3, p. 250.

${ }^{67}$ Gestoso y Pérez, Sevilla Monumental, p. 93; Falcón Márquez, La capilla, p. 40 y Valdivieso González, Historia de la Pintura, p. 84; restaurado en 1594 se pasó a lienzo en 1777 (Serrera Contreras, "Pintura y pintores", p. 366).

${ }^{68}$ Gestoso y Pérez, Sevilla Monumental, p. 94.

${ }^{69}$ Quiles García, Teatro de la Gloria, p. 196.

${ }^{70}$ Quiles García, Teatro de la Gloria, p. 32. Los rótulos acreditan obras en 1784 y 1900.

${ }^{71}$ Gestoso y Pérez, Sevilla Monumental, p. 94; en la capilla hay otras fechas, 1690 y 1747.

${ }^{72}$ Con arreglos de pino, según acreditó la intervención efectuada por Artyco recientemente. 


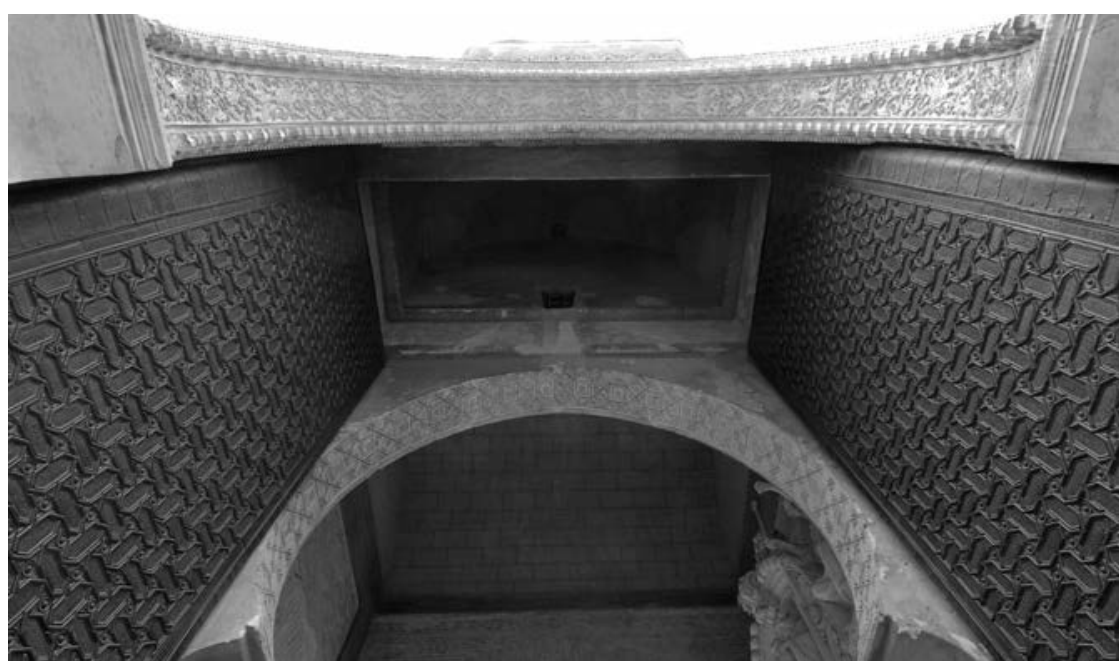

Figura 4. Vista cenital del primer tramo del zaguán, entre los arcos "I21Jn" (con decoración plateresca) en la parte superior y "I21Js", en el centro de la imagen (con decoración almohade) y las hojas de la puerta abatidas entre los dos; bajo ellos se ve la bóveda de cañón y la parte alta del arco "I20J" (Foto del autor).

"I21Jn"73. La tablazón queda oculta tras un estupendo ataujerado de bronce de casi seis mil piezas, fundidas, cinceladas y clavadas [Figura 5], formando dos composiciones gemelas, de 7,03 m por 1,74; cada una está enmarcada por 40 tiras con letreros cúficos decorados, ocho de ellas con ingletes, que repiten "Loor a Dios por sus gracias. La gratitud a Dios. La soberanía pertenece a Dios. El poder pertenece a Dios"74, cuya única anomalía es la orientación de las de la hoja de levante $^{75}$, concretamente las de la derecha, pues no se leen desde el interior de la hoja, sino desde fuera. El tema general es una lacería aparentemente sencilla ${ }^{76}$, formada por cinco clases de cintas ochavadas,

${ }^{73}$ La decoración de lazo que describiré más adelante fue parcialmente destruida para reparar el dintel de madera; en el arco "I21Jn" lo que se ve son improntas del ataujerado, que parece relieves.

${ }^{74}$ Las traducciones que ofrezco son las de Salem, "La Puerta", cuya descripción es muy rigurosa, al contrario que la de Almut von Gladiss en Ewert et al., Hispania antiqua, p. $173 \mathrm{~s}$.

${ }^{75}$ Los ingletes acreditan que es una anomalía antigua, quizás de origen.

${ }^{76}$ Terminología de Nuere Matauco, La carpintería de armar. La base es un cuadrado de $44 \mathrm{~mm}$ recortado como octógono y prolongado como estrella de cuatro; cada sino queda separado de los contiguos por la medida de su diagonal, formando esvásticas alternantes; la otra medida necesaria son los $14 \mathrm{~mm}$ de las cintas. 


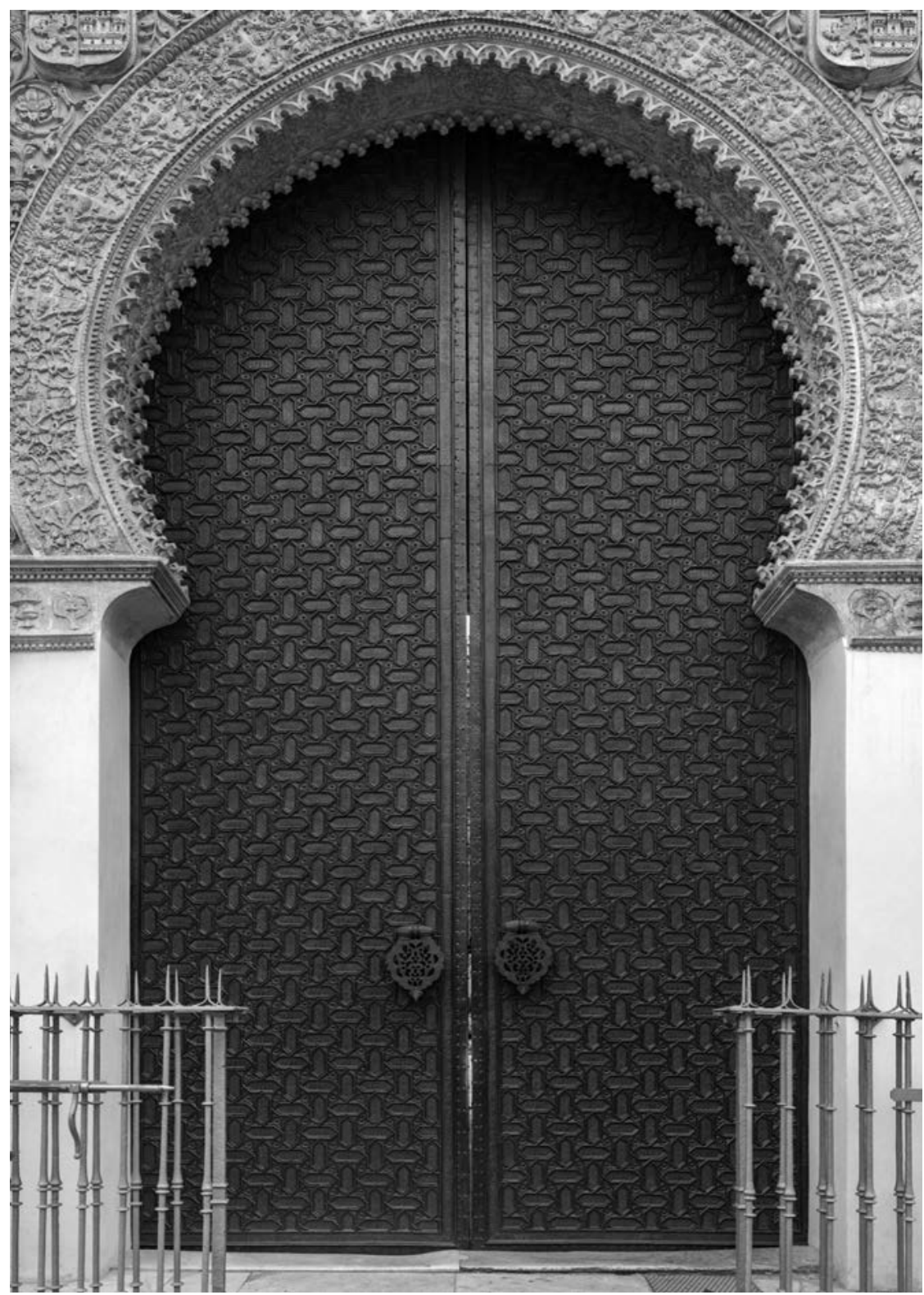

Figura 5. Detalle de la portada norte, con el arco plateresco ("I21Js"), la reja de cierre general, y las dos hojas cerradas, tras la limpieza acometida en 2013; las aldabas fotografiadas aquí son las copias modernas, realizadas en 1982 (Foto publicada con autorización de ARTYCO). 
y otras tantas de piezas poligonales; el lazo tiene un sino octogonal, con un clavito gallonado en el centro, y cuatro almendrillas, del que parten zafates redondos ${ }^{77}$ que, en los bordes, son recortados ${ }^{78}$; los horizontales, que suman 211 en cada hoja, llevan en una línea de cúfico florido dos frases "El poder pertenece a Dios. La eternidad es de Dios"; los zafates recortados, que son 58, y los 248 normales de disposición vertical, muestran decoración vegetal ${ }^{79}$; las piezas menores son 112 almendrillas, triangulares y lisas, adyacentes a las tiras periféricas. Completan el conjunto dos aldabas [Figura 6], en cuyos martillos hay letreros cursivos vocalizados que citan en árabe dialectal ${ }^{80}$ las aleyas 36 y 37 de la azora XXIV (aldaba este) y 46, 47 y 48 de la XV (aldaba oeste) y viceversa ${ }^{81}$. Se ha publicado que un trazado "casi idéntico se encuentra en el siglo IX en las yeserías que cubren el intradós de algunos de los arcos de comunicación del oratorio y el patio, en la mezquita de Ibn Tulun, en El Cairo" 82 y también en una puerta dibujada en las Cantigas $^{83}$. Las diferencias de detalles, los perfiles y la presencia de un rosario perimetral ${ }^{84}$, matizan la uniformidad sugiriendo el trabajo de varios artesanos y ciertas reparaciones hechas con pericia, como la del platero Juan Rodríguez, que repuso láminas "de cobre" en $1478^{85}$ o las de 1592 a 1606, cuando un vendaval torció el cerrojo ${ }^{86}$, pagando a Isabel de Chaves más de diez mil maravedíes por el "metal" para arreglar

77 Éstos, a pesar de tener seis lados, no son hexágonos alargados, sino rectángulos, ochavados tras eliminar los lados cortos, como atestiguan los picos a escuadra.

${ }^{78}$ Son zafates redondos, a los que un corte convierte en pentágonos.

${ }^{79}$ En muchos zafates hay rastros de bermellón y negro, acreditados en la intervención de Artyco. Al menos en el reverso de tres hay un signo grabado, como "W" ( $i$ "ayn" aislada o el numeral "4"?).

${ }^{80}$ Valencia Rodríguez, “Aldabón en la puerta del Perdón” y Valencia Rodríguez, "Aldabón”, que Salem consideró errores.

${ }^{81}$ Por detrás muestran los mismos textos, pero intercambiados; la caligrafía y la decoración son distintas en las cuatro caras.

${ }^{82}$ Torres Balbás, Artes almorávide y almohade, p. 46, es el arco "11O12" de la aljama egipcia, aplicando el sistema de Ch. Ewert; la rareza del esquema se deduce de Balmelle et al., La décor geómétrique, pp. 298-99.

${ }^{83}$ Guerrero Lovillo, Las Cantigas, p. 315 , indica que la cantiga 32 alude a un palacio episcopal ajeno a Sevilla.

${ }^{84}$ López Pertíñez, La carpintería, p. 133, llama "perlados" a estos contarios, presentes en armaduras almohades y granadinas, y también en las aldabas.

${ }^{85}$ Gestoso y Pérez, Sevilla Monumental, p. 88 y A.C.S., 1478 y 1479,11 y $25 v^{\circ}$.

${ }^{86}$ de Ariño, Sucesos de Sevilla, p. 16 y Jiménez Martín y Cabeza Méndez, Tvrris Fortissima, pp. 243 y 244. 


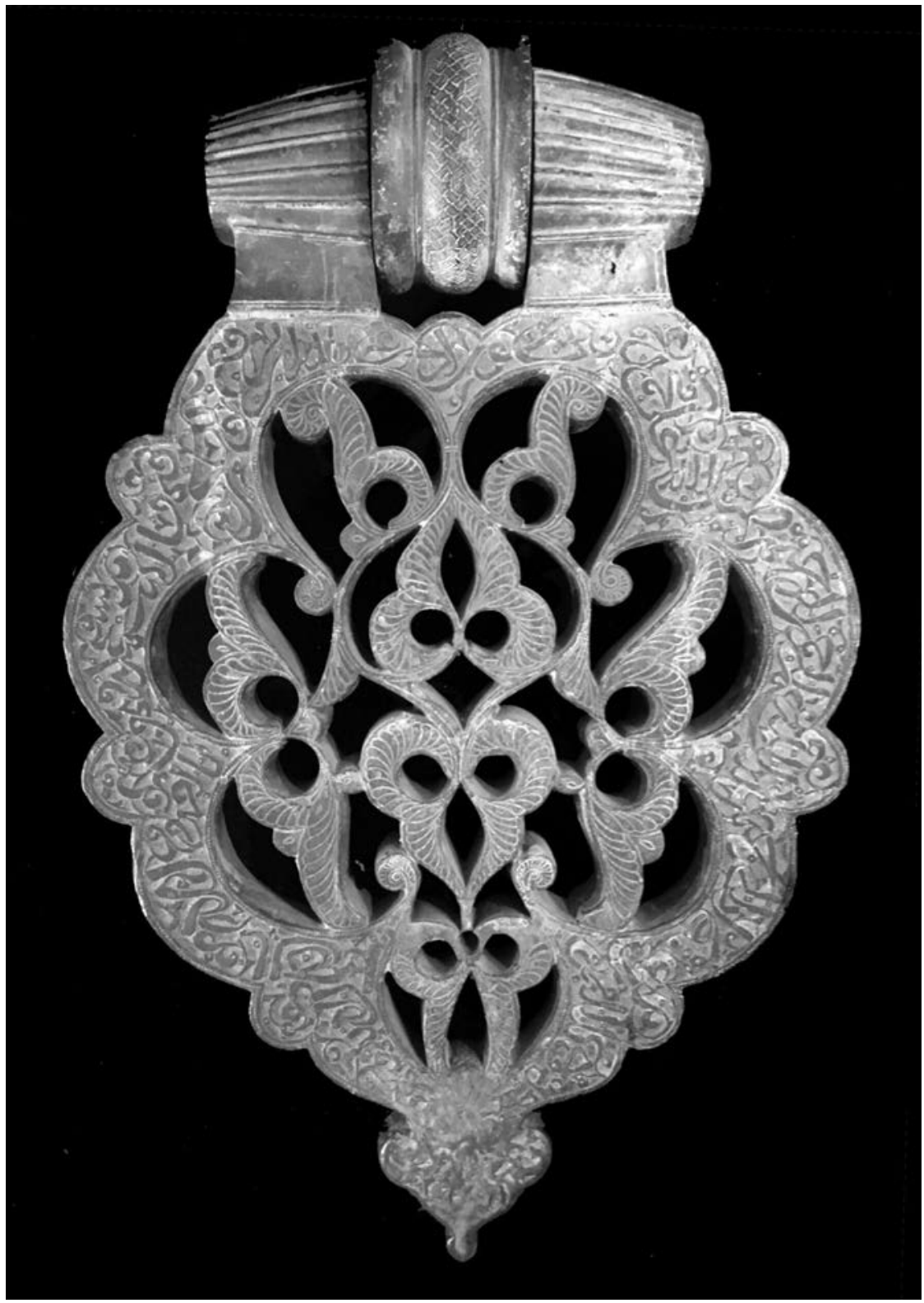

Figura 6. Fotografía actual del reverso de la aldaba original del lado de levante, conservada en una cámara de la Giralda; es la cara mejor conservada, salvo el agujero axial de la parte baja, al inicio de las palmetas inferiores, que debió ser hecho en el siglo XX para impedir el movimiento (Foto del autor). 
la puerta ${ }^{87}$. En 1885, según Gestoso y Pérez, que consideraba el ataujerado como mudéjar y hecho en 1478, se limpiaron dos "tarjetillas" para ensayar la limpieza general ${ }^{88}$. Desde los años cincuenta del siglo XX se han sucedido medidas protectoras hasta que en 1985 se sustituyeron las aldabas.

Una publicación reciente aporta paralelos, como la existencia, en una colección británica, de dos aldabas más pequeñas y lisas, pero tan parecidas que cabe suponer que proceden de otra de las puertas de la aljama ${ }^{89}$; también estudia este artículo la técnica para fundir las piezas, así como sus vínculos con letanías mágicas ${ }^{90}$. La datación exacta de estas hojas constituye un problema sin resolver: Martínez Núñez menciona que uno de los textos citados se lee también en la Bāb Agnāw de Marrakech, de 1188, y menciona los zafates epigráficos en relación con la decoración de las puertas de la Qaṣba de los Ūdāya, de Rabat, de $1194^{91}$; otro arabista, Valencia Rodríguez", las lleva al "Final siglo XII, c. 1196". Por todo ello las supongo hechas en la última década del dicho siglo, como remate de las obras de la aljama y la construcción de la Alcaicería, tan vinculada a la puerta del Perdón.

El espacio donde giran las hojas lleva un friso ${ }^{93}$ de $1,08 \mathrm{~m}$ de altura [Figura 7] formando un paño de lazo de ocho con cintas a calle y cuerda, rematado por una nacela, sobre la que vemos una bóveda rebajada, estribada en los muros de levante y poniente y en cuya clave, que está en la misma cota de la cornisa exterior, vemos una perforación que, mediante dos roldanas, permitía tañer las campanas. Tras ellos aparece el primer arco del zaguán, "I21Js" [Figura 8], con decoración almohade en el desarrollo cilíndrico de su rosca ${ }^{94}$, contenida en un

${ }^{87}$ Gestoso y Pérez, Sevilla Monumental, p. 89; los datos en A.C.S., 1606, 11 (180 y 183).

${ }^{88}$ Gestoso y Pérez, Sevilla Monumental, p. 88.

${ }^{89}$ Así lo imaginó Ortiz de Zúñiga, Annales 3, p. 251.

${ }^{90}$ Nickson, "'Sovereignty belongs to God"”.

${ }^{91}$ Martínez Núñez, "Yeserías epigrafiadas", p. 171; Martínez Núñez, "Ideología y epigrafia”, p. 14; Martínez Núñez, "El Corán”, pp. 140 y 172 y Martínez Núñez, "Hisba y ŷihād", p. 125, señala que aparece en inscripciones de Jaén, de época de Abū Yūsuf Ya quāb al-Manșūr (1184-1199) y Muhammad al-Nāṣir (1199-1214).

${ }_{92}$ Valencia Rodríguez, “Aldabón en la puerta del Perdón”, p. 196.

${ }^{93}$ En Almagro Gorbea et al., Atlas arquitectónico, p. 16; Almagro Gorbea, "De mezquita", pp. 15 y 16 usó el tema de lazo en las restituciones. En el negativo 3-13542 de la Fototeca del Laboratorio de Arte de la Hispalense se advierte que el 27 de agosto de 1945 estaba en obras, las del proyecto A.G.A., 1944.

${ }^{94}$ Salem, "La Puerta", p. 201-202. 


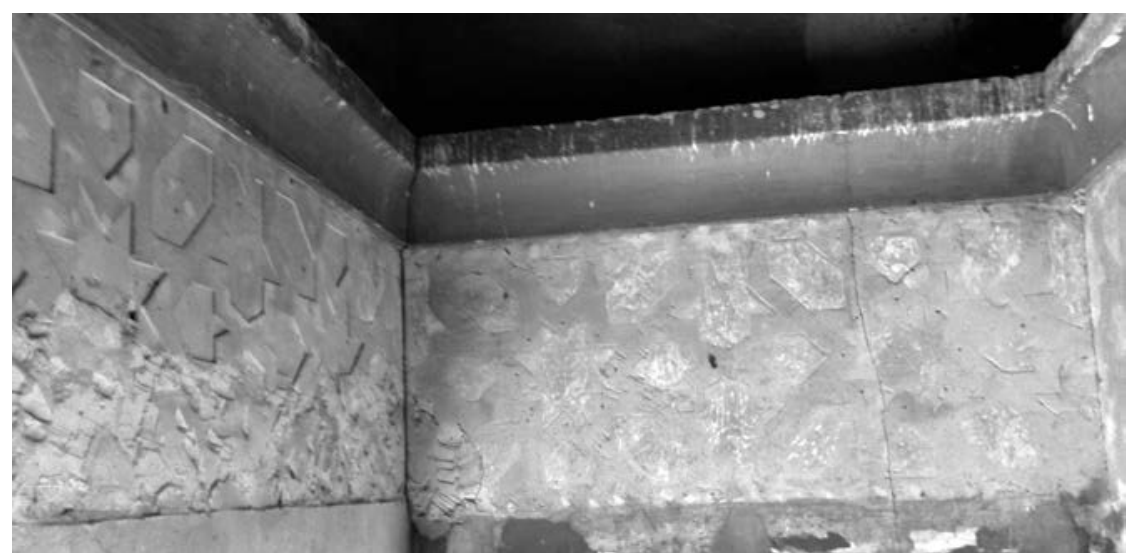

Figura 7. Friso con decoración de lazo, ubicado sobre el espacio de las mueven las hojas de la puerta; en el lado izquierdo se observa que casi la mitad inferior está picada intencionadamente y que es nueva la banda lisa que cubre el dintel, señales de que éste fue reparado en algún momento (Foto del autor).

Figura 8. Decoración del arco "I21Js"; en la parte izquierda de la imagen, que corresponde al lado sur, se observa prácticamente completo el conjunto de molduras que enmarcan el panel decorativo de cuadrados, mientras en el lado izquierdo ha desaparecido casi por completo (Foto del autor).

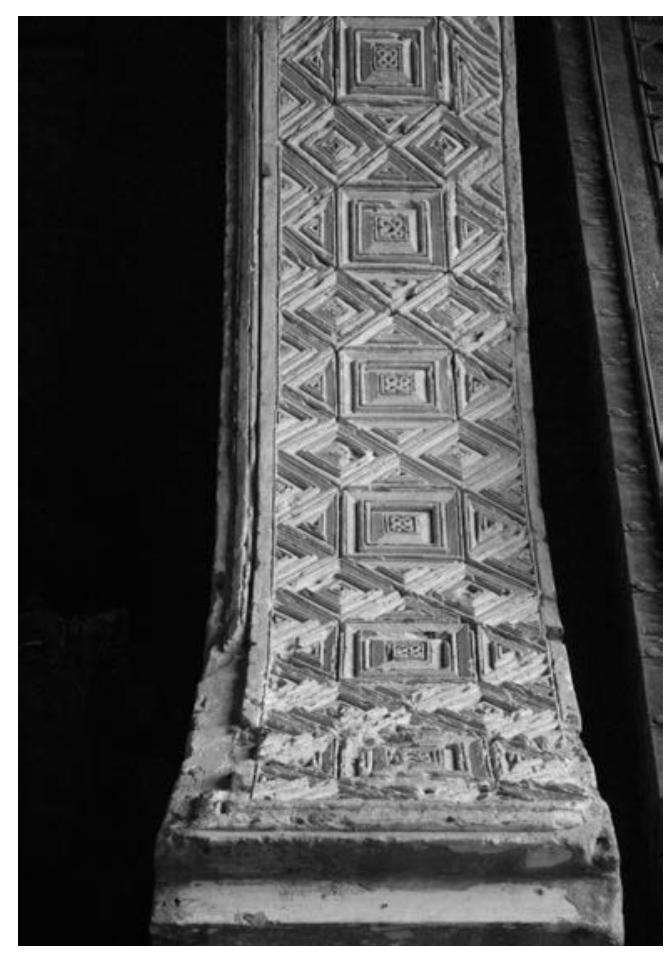




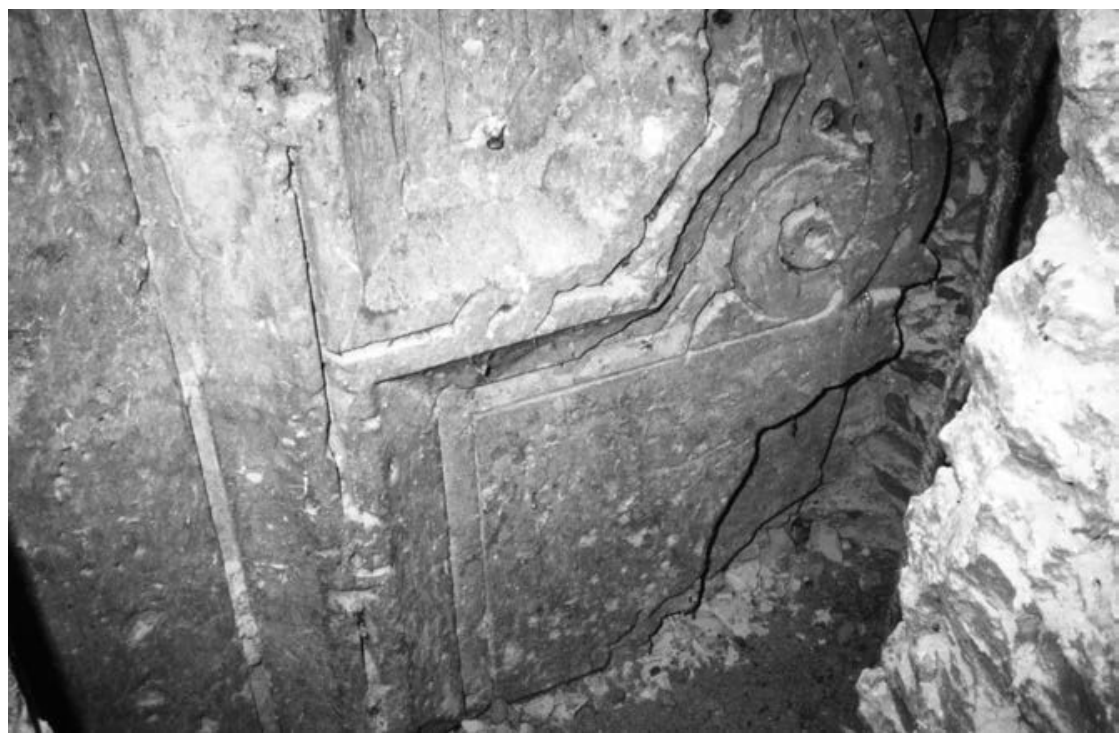

Figura 9. Decoración del lado norte del arco "20I21" en la parte del salmer serpentiforme, conservada detrás del ático del retablo del Ecce Homo; corresponde al mismo diseño de la conservada en el lado noroeste del arco "I20J", donde se ha perdido la parte que llega hasta el rincón (Foto del autor).

"marco" formado por molduras continuas, que recorren las aristas; contiene la rosca una secuencia de cuadrados ${ }^{95}$ y medios cuadrados, yuxtapuestos por los vértices, a los que se superponen otros en igual disposición; los restos del "marco" permiten deducir que este arco ha perdido, por la parte de los batientes, su decoración antigua, mientras que por la cara sur se conserva bastante e incluso queda algo sobre el retablo del Ecce Homo, que permite entender como estaba terminada su cara meridional. El arco "20I21" no tiene decoración, pero como el trozo que existe sobre el citado retablo vuelve hacia él, es seguro que también la tuvo [Figura 9]. El arco "I20J" es muy conocido, pues es el que conserva más y mejor revestimiento islámico, estando el tema vegetal de su calle central flanqueado por un desarrollo geométrico similar al del arco "I21 Js" [Figura 10]. Teniendo en cuenta esta ordenación, y que estos conjuntos decorativos surgen de una misma cota, entendemos que formaban parte de un proyecto decorativo unitario, cuyo ele-

${ }^{95}$ Sólo la observación distraída de algunos guías turísticos los confunde con rombos, síntoma de que no han leído a Salem, "La Puerta", p. 201. 


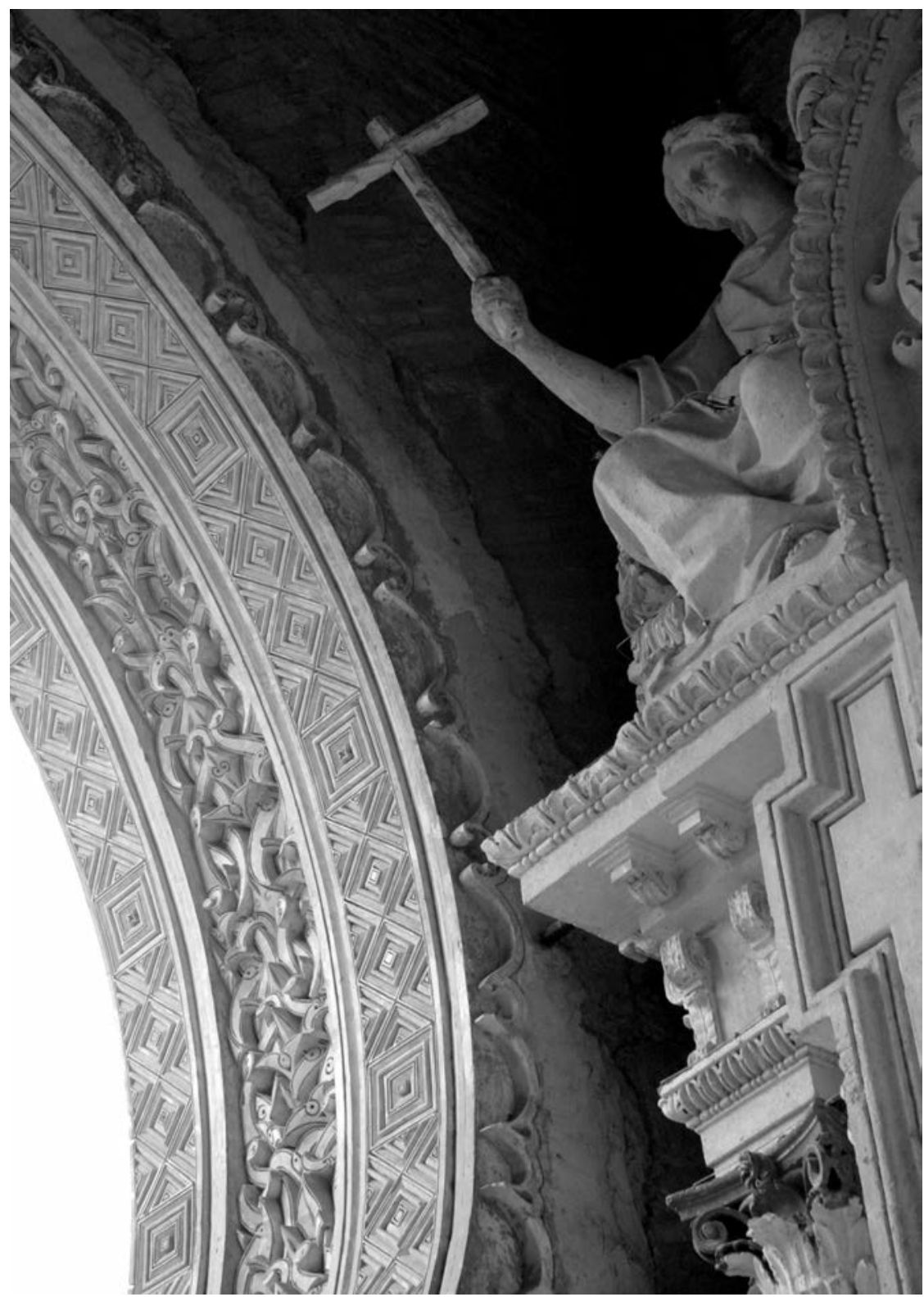

Figura 10. Decoración del lado noroeste del arco "I20J" junto al lado sur de las cornisas de la portada de la Caridad donde se conserva la arquivolta "de hojas", pero no la continuación de su paño hasta el rincón, que se puede completar con las figuras precedentes (Foto del autor).

Al-Qantara XXXVIII 2, 2017, pp. 287-332 ISSN 0211-3589 doi: 10.3989/alqantara.2017.010 
mento esencial vemos en la cara norte del "I20J"96, conformando una arquivolta compuesta por:

1. Una imposta que repite la del arco, en forma de tarjeta lisa recortada en nacela.

2. El salmer, constituido por el motivo "serpentiforme" más simple, una "S"

3. Una arquivolta, que Navarro y Jiménez denominan arco de hojas, rematada por un lóbulo en la clave, que obligó a rebajar el ladrillo subyacente.

4. En los arcos "I21Js", "20I21" e "I20J" el esquema, presente en todos los arcos de la mezquita que tienen recubrimiento ${ }^{98}$, está enriquecido con lazos.

Lo importante es que, estando la estructura de ladrillo decorada per se [Figura 11], como muestran los lóbulos de las dos caras del arco

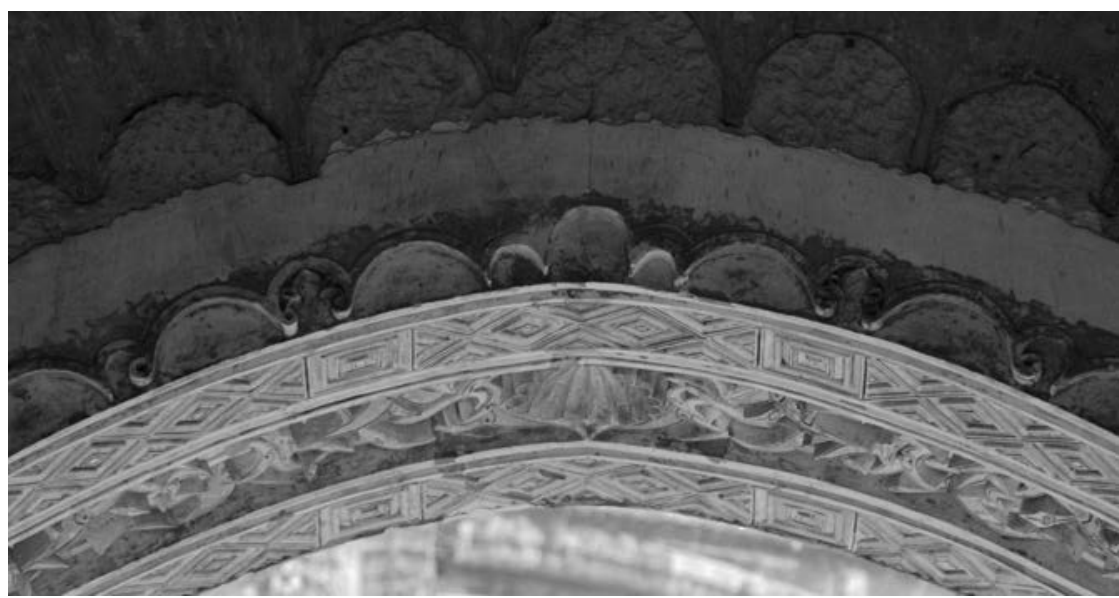

Figura 11. Decoraciones almohades sucesivas de la cara norte del arco "I20J"; se aprecia arriba la primera arquivolta, con un sencillo lobulado en relieve, que quedó oculta bajo una gruesa de estuco; este añadido disminuyó la luz del arco y sirvió de soporte a la arquivolta "de hojas" (Foto del autor).

${ }^{96}$ Además, permite saber cómo era la de "A13B", "B13C", "13C14" y "M20N"; dibujos en Almagro Gorbea et al., Atlas arquitectónico, p. 42. La cara sur del "I20J" estuvo decorada igual.

${ }^{97}$ La mutación de los arcos tectónicos (lisos o lobulados) que dio origen al motivo serpentiforme empezó en los del oratorio de La Aljafería salvo en el de su mihrāa (datado entre 1065 y 1110, según Calvo Capilla, Las mezquitas, p. 705), posteriormente se desarrolló en África y finalmente se generalizó en lo almohade (Navarro Palazón y Jiménez Castillo, Siyasa, p. 282). 
"I20J", el recubrimiento lo ocultó todo, pues la decoración añadida no se ciñó a las formas previas. Para concluir la descripción de esta parte [Figura 12] indicaré que sobre los alfices existe una cornisa que corona

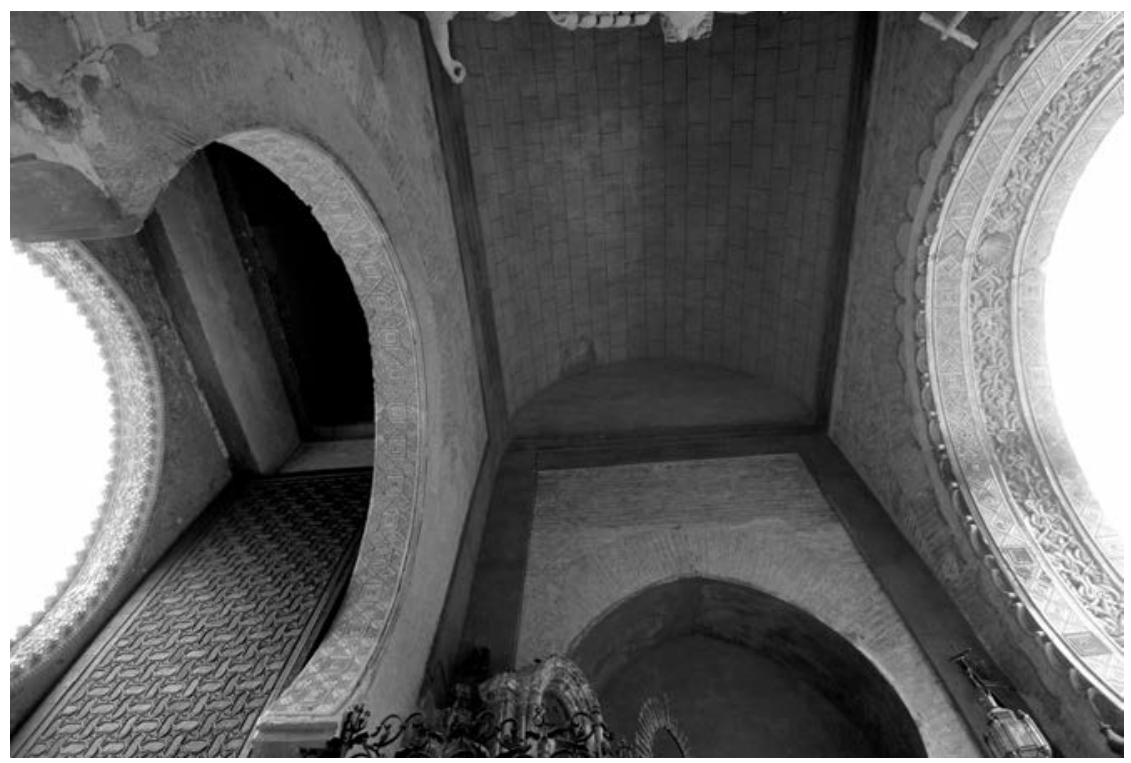

Figura 12. Partes altas del espacio del zaguán desde la portada de la Caridad; de izquierda a derecha: arco "I21Jn", hoja de levante, friso de lazo, arco"I21Js", la reja y ático del retablo del Ecce Homo, arco "20I21", bóveda de cañón, farol de san Millán y finalmente el arco "I20J" (Foto del autor).

todos sus paramentos verticales, de la que arranca una bóveda de cañón orientada en sentido este-oeste ${ }^{99}$, peraltada para igualar con la que cubre el espacio sobre las hojas; no hay más que ver la sección de Almagro Gorbea $^{100}$ [Figura 13] para entender que esta estructura se hizo para la estabilidad de la espadaña y que ha funcionado bastante bien pues en el cabildo del 20 de diciembre de 1799 "Se leyó un parecer del Maestro de obras de esta Santa Iglesia Manuel Núñez, haciendo presente se havian desprendido varios fragmentos de la bóbeda que cubre el tránsito

${ }^{98}$ Es decir, los arcos, "A13B", "B13C", "13C14" y "M20N".

${ }^{99}$ Esta bóveda es de ladrillo; el revestido actual es de 1992 siguiendo los rastros existentes de la obra de 1800, que igualaban esta parte con todo el exterior del patio, según había quedado en 1792 (véase nota 110).

${ }^{100}$ Almagro Gorbea et al., Atlas arquitectónico, p. 16. 


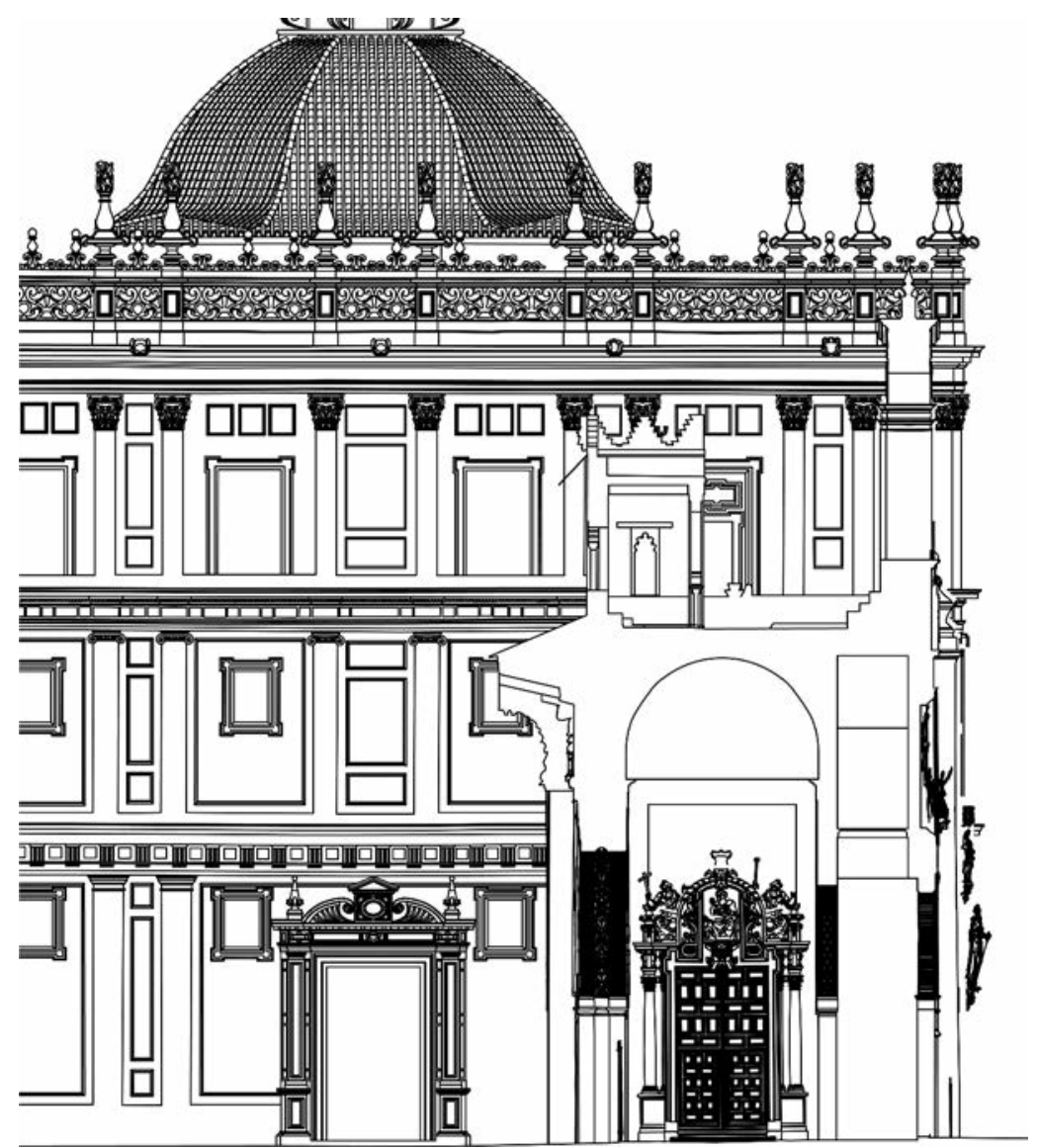

Figura 13. Esta restitución fotogramétrica publicada en 2007 da cuenta de la fragilidad del arco "I21Jn" (debilitado por el relieve) para sostener la espadaña; por ello hicieron la bóveda rebajada y los escalones que permiten cargar sobre todo el contorno (Fragmento de la lámina 16 del Atlas Arquitectónico de la Catedral de Sevilla).

de la Puerta del Perdón la noche del día 10 del corriente mes, con motibo del huracán y lluvias que se experimentó: y el cabildo acordó que los Sres de fábrica cuiden que se haga la obra con la economía posible" ${ }^{101}$, la obra de la bóveda se hizo pero seguramente lo que restaba del mirador quedó como lo muestran las imágenes el XIX.

${ }^{101}$ A.C.S., 1799, 142v, la reparación incluyó otras partes, pues Gestoso y Pérez, Sevilla Monumental, p. 89, recuerda el hallazgo de la inscripción CIL II-1167 en una jamba, como las de las esquinas de la Giralda. 
El arco "I20J", como corresponde a su privilegiada ubicación, es el mayor de los que se conservan, mostrando su cara sur las molduras que enmarcan la decoración añadida, la potencia del relleno necesario para implementarla, la rosca estructural lisa, la arquivolta lobulada de ladrillo y el correspondiente alfiz, concluyendo con una cornisilla ubicada en la cota de la de la bóveda, y a la misma altura, y con un perfil similar a la de los arcos adyacentes. Encima aparece un tercer tejaroz, que es obra de Hernández Giménez [Figura 14], sobre cuyas últimas cobijas, tras un tramo liso, existe un listel discontinuo, acreditado en imágenes antiguas $^{102}$; éste es la base compositiva de los tres muros del mirador, de los que el meridional posee tres ventanas y dos paños decorativos, mientras los otros sólo tienen un hueco cada uno; el hueco de levante es el más sencillo, pues lo forma una herradura apuntada de ladrillo con alfiz simple; el opuesto y los laterales del frontal, llevan rosca lo-

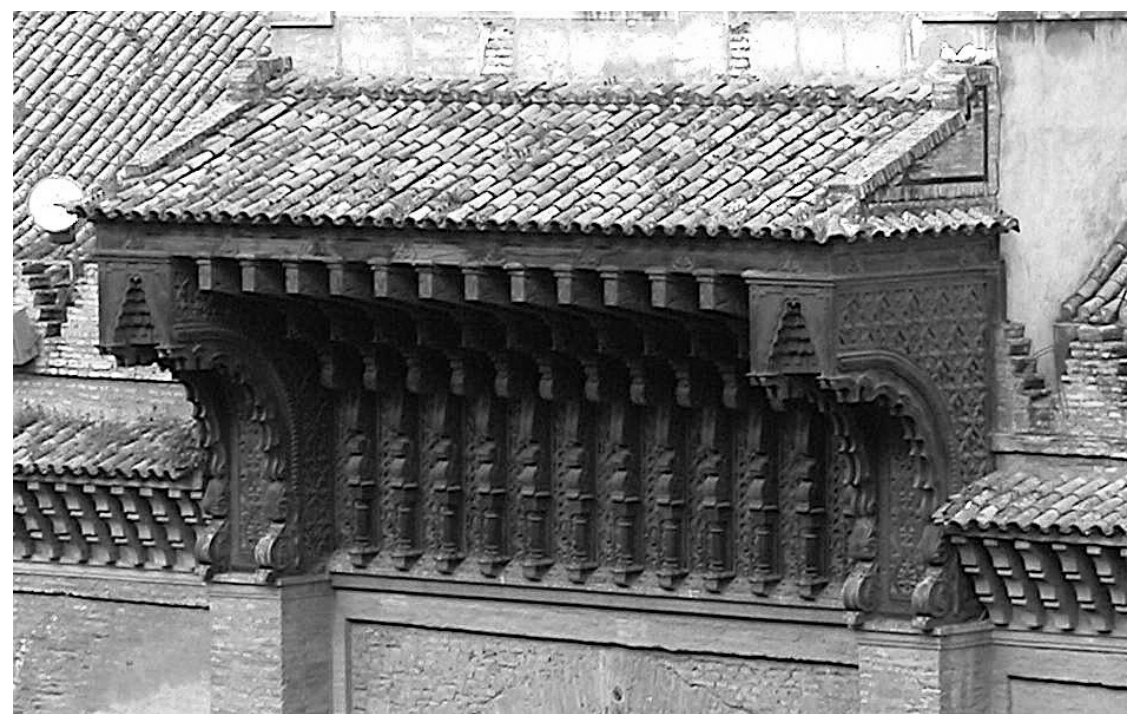

Figura 14. Parte superior de lo que queda de la arquivolta lobulada del arco "I20J", en su versión primigenia, recuadrado por su alfiz; sobre ellos vemos el tejaroz diseñado y construido por Hernández Giménez; sobre las últimas tejas del tejaroz se inicia el paramento del mirador o torreón (Foto del autor).

${ }^{102}$ Un dibujo de 1832 (Rodríguez Barberán, "Sevilla en tiempos", p. 220) y una foto de hacia 1872 (Uceda Valiente et al., Sevilla artística, p. 105) acreditan los remates redondeados de los estribos del patio, que Hernández Giménez cambió por ménsulas serpentiformes. 
bulada y su alfiz presenta dos parejas de "picos" que invaden las albanegas; el hueco central es una bífora de rosca bilobulada, con fuste de mármol y capitel califal en función de parteluz y los mismos "picos"; los paños son de katf wa-dāry emparchado, de formato pequeño, enlucido y repintado tres o más veces [Figura 15]. Concluye el conjunto con otro listel y once merlones de seis gradas, cinco de los cuales son frontales y completos, dos angulares, dos laterales completos y dos medios en los extremos ${ }^{103}$. Por el interior se advierte que cada ventana está

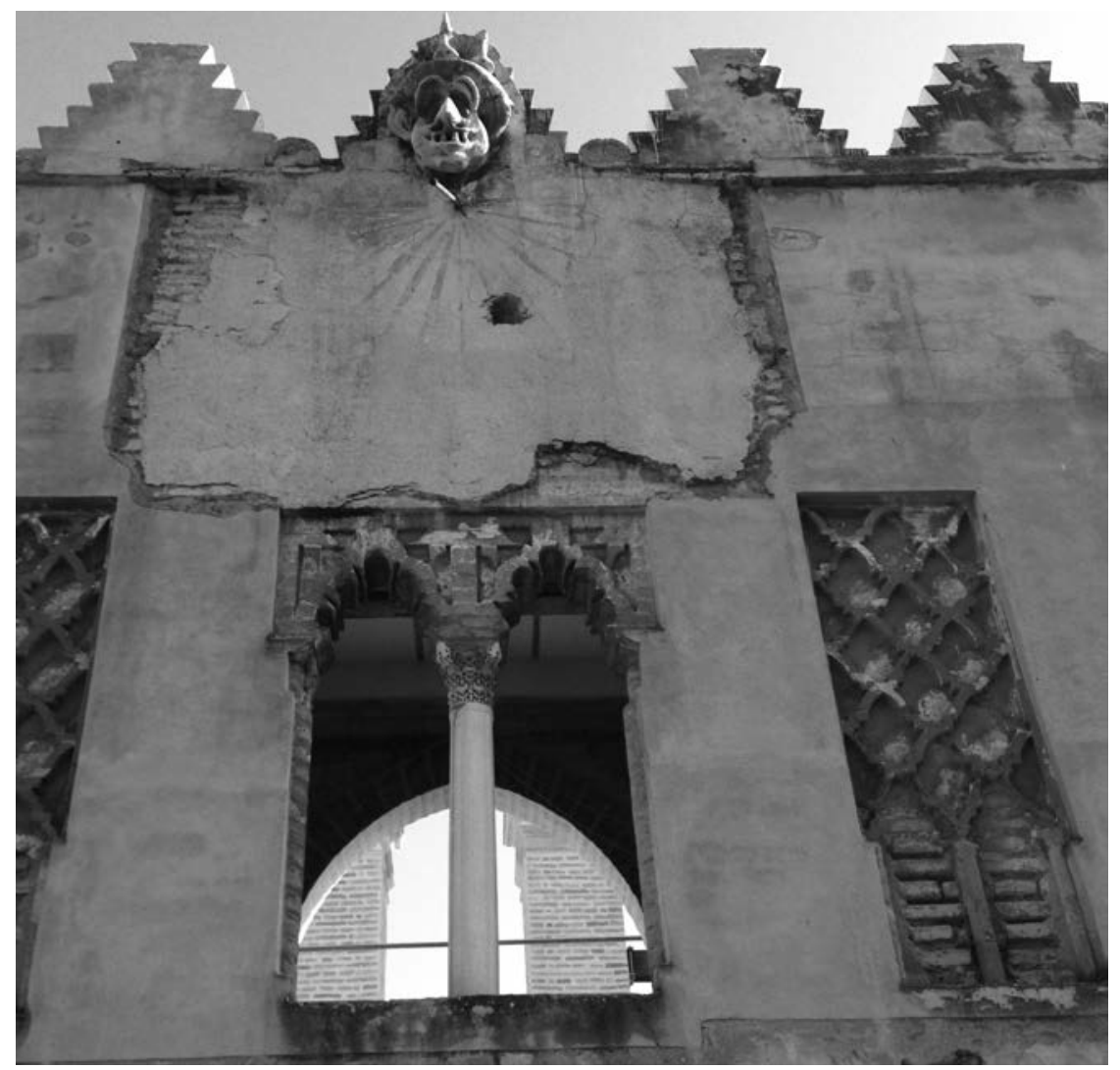

Figura 15. Parte central de la fachada sur del mirador antes de las obras de restauración de 2014; destaca la bífora central, con capitel califal; los arcos de esta ventana, de ladrillo visto y rosca bilobulada, con su alfiz de dos picos; a izquierda y derecha aparecen los paños decorativos (Foto del autor).

${ }^{103}$ Éstos (de seis gradas) son distintos de los del patio, de cuatro; en época almohade fueron de cinco, a juzgar por los exteriores. 


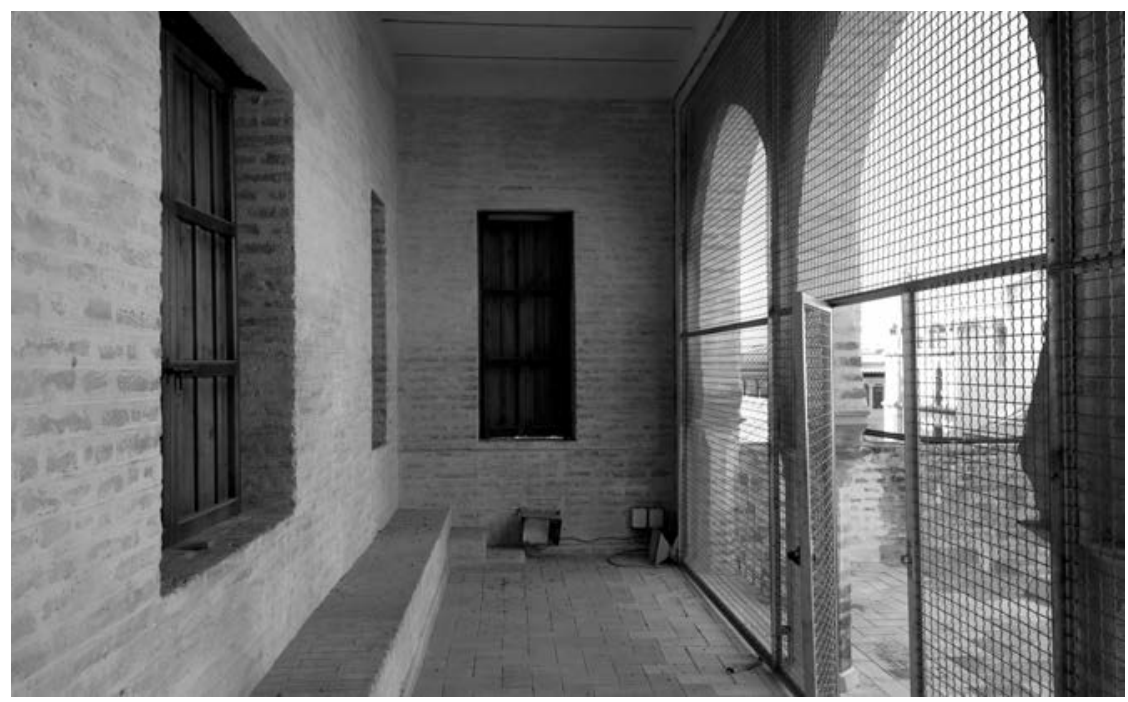

Figura 16. El espacio del torreón tras las obras terminadas en 2014; salvo las ventanas de madera y la malla, todo está como lo terminó Hernández Giménez; destacaremos los dinteles originales, con sus gorroneras, y el relej bajo el hueco de la ventana lateral (Foto del autor).

alojada en un tabuco adintelado cuyas ranguas originales permiten girar las hojas [Figura 16]; el muro frontal mide $60 \mathrm{~cm}$ de espesor y los flancos sólo 47, pero éstos, un poco por debajo de los alfeizares de sus ventanas, se reducen hasta 44 , con lo que se producen sendos relejes que coinciden con el listel exterior; la única explicación de esta reducción es que desde aquí hacia arriba los flancos se labraron sobre el pretil, mientras el muro meridional se rehízo desde más abajo. Unos dibujos de $1832^{104}$ indican que, tras los merlones, había un tejado que vertía hacia el norte, cuya ruina acreditan las fotografías ${ }^{105}$ [Figura 17], que además demuestran que al poco construyeron una escalerilla para acceder al mirador a través de una gatera ubicada bajo la ventana [Figura 18].

Los tres muros, y otros tantos arcos de herradura túmida sobre dos pilares, delimitan el estrecho y largo espacio interno del mirador; su pavimento queda algo más alto que el del resto de la azotea, a la que hoy se accede desde el adarve del muro exterior gracias a dos escalerillas con boveditas de aristas apuntadas, que en su momento tuvieron

${ }^{104}$ Dibujos de Harriet Ford y de Roberts, citados.

${ }^{105}$ Foto, citada, de Laurent, de hacia 1872. 


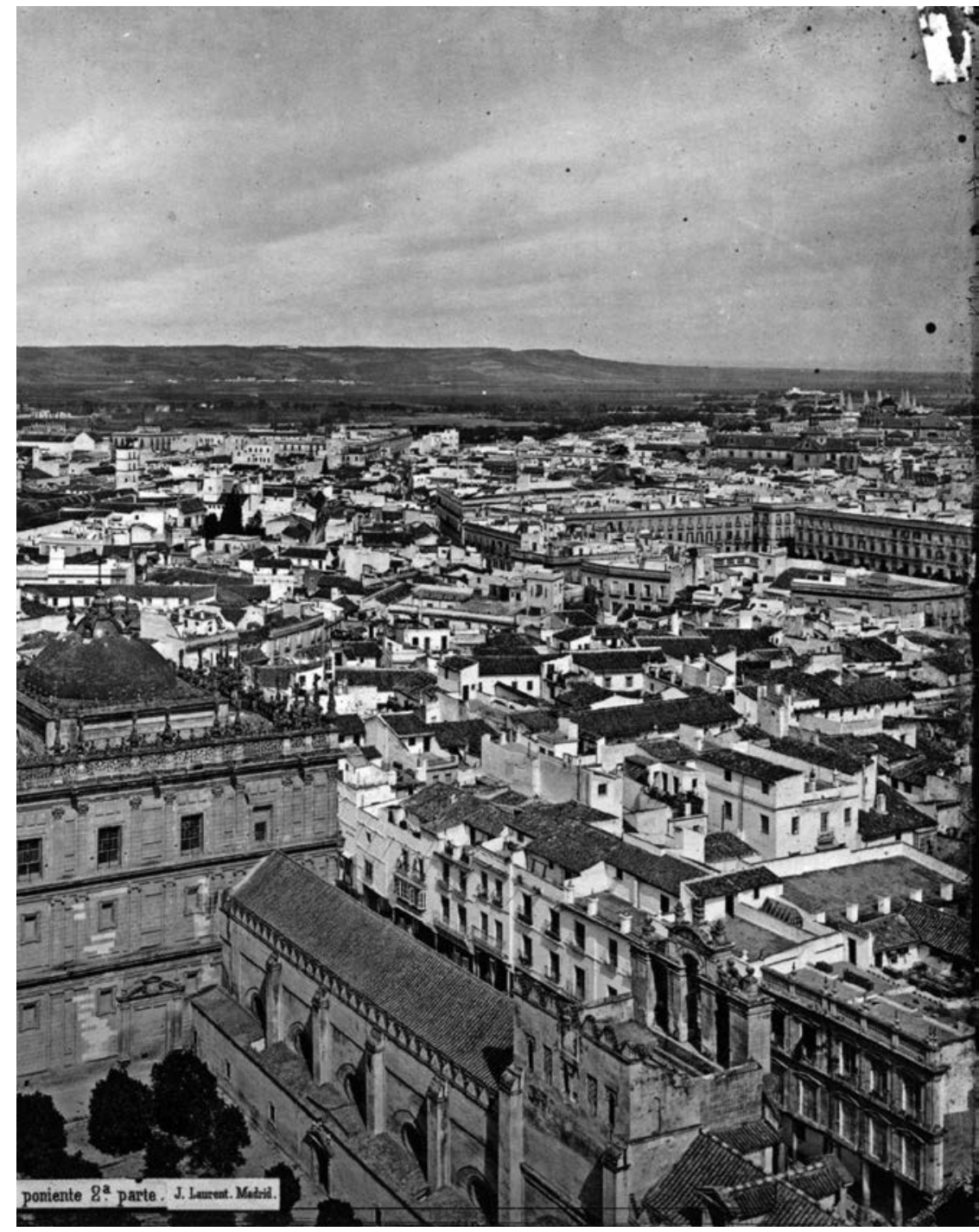

Figura 17. Fragmento de una fotografía de Jean Laurent tomada hacia 1872. Se aprecia que el mirador estaba en alberca, que sus costado se prolongaban hacia la espadaña en forma de dos tapias, decoradas con un aparejo simulado de sillares (Foto de la colección del autor, depositada en la BCC). 


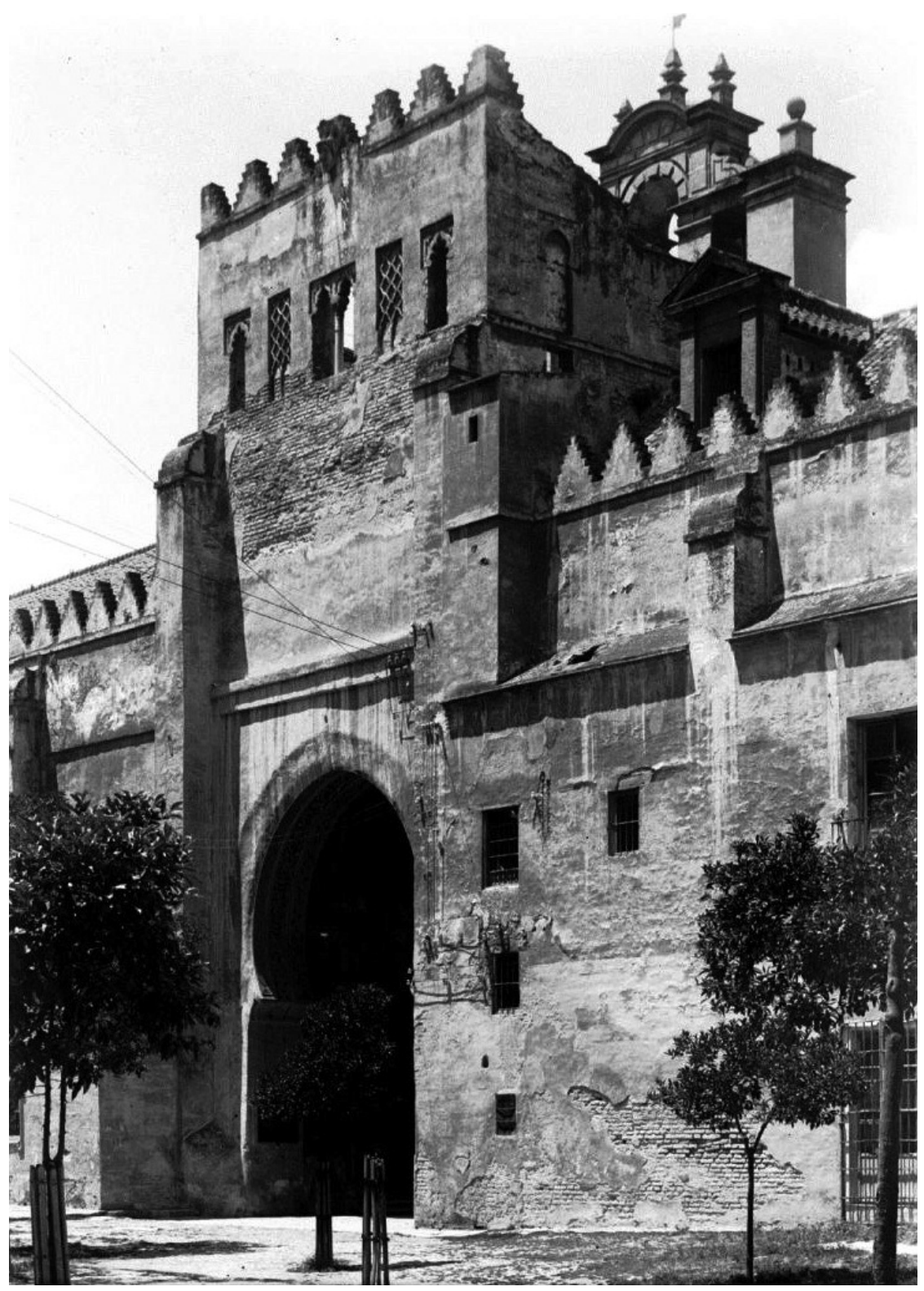

Figura 18. Esta foto, anterior a 1922, muestra que los estribos del "Sagrario Viejo" estaban englobados por una vivienda, cuya escalera terminaba sobre el estribo "I20", salía al tejado y daba paso al trasdós de la bóveda del zaguán por una gatera bajo la ventana de levante (Fototeca del Patrimonio Histórico WUN-04007). 
puertas. En 1948 Hernández Giménez proyectaba restituir "[...] las partes desaparecidas, de los muros, de la arquería posterior y del almenado, del cuerpo organizado probablemente en la primera mitad del siglo XV sobre la antedicha puerta para resguardar de la lluvia y del sol a quienes tuvieran que presenciar, desde tal sitio, las ceremonias a que sirviera de escenario el Patio de los Naranjos [...]. La reposición de la cubierta del cuerpo acabado de citar, de la que no hay certeza, de si seria de tejado o de solera de azotea, pero que, en cualquiera de ambos casos, asentaría sobre un entramado de madera, cubierta que, no constituyendo organismo visible desde los lugares visibles del monumento o desde fuera de este, todo aconseja organizar de la disposición indicada en último termino, menos siempre propicia a recalo que la de tejado"106, que fue la opción elegida, aunque sobre viguetas metálicas; consta que empezó las obras en $1945^{107}$ derribando la escalera del XIX y documentando mediante dibujos la existencia de los dos soportes laterales y las jarjas de otros tantos $\operatorname{arcos}^{108}$. El espacio al descubierto, entre éstos y la espadaña, estaba cerrado por unas tapias laterales, que en la foto de 1872 imitaban sillares ${ }^{109}$; al rebajarlas halló parte de un merlón de gradas ubicado junto al caballete del tejado del lado del Sagrario, como atestigua la memoria de otro de sus proyec$\operatorname{tos}^{110}$ "[...] es de advertir, que la actual altura del indicado cuerpo, no es la de las postrimerías del siglo XII, al haber sido aumentada la de entonces, muy adentrado el siglo XV, con la correspondiente a una torreta — obra del mudéjar en boga a la sazón en Sevilla — adicionada ligeramente por encima de la acometida de la cubierta del alero a ese cuerpo mismo, adición que proporcionó al conjunto esbeltez mayor que la originaria, $y$, aun, tal vez excesiva. Depone, sin embargo, acerca de la originaria altura de ese cuerpo, lo subsistente, todavía, del almenado que - muy poco por encima del nivel de caballete de las inme-

${ }^{106}$ A.G.A., 1948.

${ }^{107}$ Gómez de Terreros y Guardiola y Díaz Zamorano, "La restauración”, p. 46.

${ }^{108}$ En el dibujo de sección conservado en su legado al Museo de Córdoba, aparece además la clave de la bóveda del zaguán, $37 \mathrm{~cm}$ bajo la solería de entonces; en 2013 hallamos restos de otros dos suelos, uno a $7 \mathrm{~cm}$ de profundidad y otro, de mayor calidad, a $20 \mathrm{~cm}$.

${ }^{109}$ Una foto de 1862 demuestra que era la renovación del acabado de 1792, fecha en que "enlucieron los muros de la parte del Norte hasta la torre imitando mampostería" (Matute y Gaviria, Anales, p. 128) y cuyos restos hemos documentado y permanecen vistos entre los estribos de la fachada de Alemanes.

${ }^{110}$ A.G.A., 1971. 
diatas galerías - coronaba los muros de contorno de aquél [...]"; es decir, tenía dos razones para identificar la torreta como obra cristiana: la existencia del almenado ${ }^{111}$, que aún puede verificarse, y la fecha atribuida al mirador, quizás basada en la publicación más solvente que existe sobre el mudéjar sevillano.

En octubre de 1930, el rector de la universidad hispalense solicitó al Cabildo que don Diego Angulo pudiera subir a la terraza de la puerta del Perdón ${ }^{112}$ para tomar datos para la lección inaugural del curso 193233; su publicación incluyó apreciaciones sobre los alfices de "dos picos", empezando por la parroquia sevillana de San Martín, cuyo "testero plano [también] puedo citarlo en una iglesia de una sola nave totalmente abovedada de estos primeros tiempos como es la de Puebla del Río [...]. Nota interesante digna de ser subrayada [de la iglesia de Puebla] es el mudejarismo de sus ventanales. En el frente exterior de la ventana del lado del Evangelio el ángulo de las albanegas presenta la decoración de doble pico de la Puerta del Perdón de la Catedral, que veremos también en un rosetón de la iglesia de Hinojos" 113 , incluyendo esta última entre las "Iglesias con capilla mayor morisca: El Aljarafe, Palma el Condado, Castilleja de Talara, Gelo, Benacazón, Hinojos [... creo que] casi todos ellos son de fecha relativamente avanzada"114; la fecha de la iglesia de Puebla quedó en el aire, pues su paralelo estructural, San Martín ${ }^{115}$ y “el mudejarismo de sus ventanales", parecen llevarla al siglo $\mathrm{XV}$, lo que contradice la mención de "estos primeros tiempos", datación que se apoya en un privilegio de 1272 concedido a La Guardia, alquería de Sevilla antecesora de Puebla del Río, que preveía instalar 200 pobladores en su extenso término ${ }^{116}$; es decir, para dar el terminus post quem de la iglesia de Puebla, y con ella la fecha de

${ }^{111}$ Este merlón, al que faltan gradas, aparece en Almagro Gorbea et al., Atlas arquitectónico, p. 16 y Almagro Gorbea, "De mezquita”, p. 22.

${ }^{112}$ A.C.S., 1930.

${ }^{113}$ Angulo Íñiguez, Arquitectura mudéjar, pp. 30 y 125.

${ }^{114}$ González Gómez y Carrasco Terriza, Catálogo Monumental, p. 255 interpretan que Angulo la clasificó en el XV, recordando además que el paramento del óculo lleva por dentro "un arco apuntado rehundido, decorado con pinturas murales de la época de los Reyes Católicos, de temas santiaguistas [...]".

${ }^{115}$ Escudero Merchante, La iglesia, pp. 24 y 26 indica que la portada de la iglesia es de 1342 llevando a 1421 la capilla que se relaciona con ella (Angulo Íñiguez, Arquitectura mudéjar, p. 127); sus terceletes son tardíos, pues se voltearon en Sevilla hasta bien entrado el siglo XV.

${ }^{116}$ González Jiménez, Diplomatario andaluz, p. 418. 
San Martín, Angulo Iñiguez dio por cierto el éxito de la repoblación de La Guardia en el XIII ${ }^{117}$, y además vinculó a este poblamiento el gran edificio abovedado actual ${ }^{118}$, cadena de suposiciones que no casa con los paralelos estilísticos citados, por lo que conviene examinar el tema con detenimiento.

Estos potentes y sencillos alfices de ladrillo de doble "pico" del mudéjar sevillano, vienen de los delicados ápices de lazo de las yeserías almohades de Cieza, del XIII ${ }^{119}$, que un siglo después dieron complejas composiciones en Granada, como las del arco occidental de la puerta del Vino, la portada del corral del Carbón y las trompas de esquina de la puerta de la Justicia ${ }^{120}$, y en Marruecos, como en la puerta de la necrópolis meriní de Chellah ${ }^{121}$ o en la del oratorio fesí de "Jama' Ez Zhar (sic)", de $1357^{122}$. Los ápices, no los "picos", se copiaron en edificios mudéjares, como la reforma de la puerta del Perdón cordobesa, de $1377^{123}$, en la torre de la Atalaya de Jerez de la Frontera ${ }^{124}$, de $1449^{125}$, en una puertecita del claustro de Lebrija (Sevilla) ${ }^{126}$, posterior a $1474^{127}$, y en yeserías de las casas sevillanas de Pilatos y las Dueñas, posteriores a 1481 .

La documentación catedralicia no data el mirador, pero ayuda a situarlo en el contexto funcional. Desde 1427 anotaban de forma específica las rentas generadas por las propiedades de la Fábrica, y desde 1446 fueron muy sistemáticos ${ }^{128}$; pues bien, en 1496, 1497 y 1498 un racionero pagó $1.200 \mathrm{mr}$ por la "de la tribuna sobre la puerta del Perdón

${ }^{117}$ El nuevo y sugestivo topónimo, documentado en 1353 (González Jiménez, La repoblación, p. 128), sugiere una refundación, sin mucho éxito (Borrero Fernández, "Realidad económica y social" documenta que en 1407 sólo tenía 30 vecinos y que no llegó al centenar hasta 1486).

${ }^{118}$ Aranda Campos, "El templo parroquial", p. 85 la lleva al XIV.

${ }^{119}$ Arco en la planta alta de la casa 10 (Navarro Palazón y Jiménez Castillo, Casas y palacios, p. 136, fig. 81s).

${ }^{120}$ Fernández Puertas, La fachada del palacio, pp. 117, 105 y 283.

${ }^{121}$ Fernández Puertas, La fachada del palacio, p. 89.

${ }^{122}$ Así lo denomina Maslow, Les Mosquées, XXIX, foto 59.

${ }^{123}$ Jordano Barbudo, "La puerta", p. 24.

${ }^{124}$ Angulo Íñiguez, Arquitectura mudéjar, pp. 160-162.

${ }^{125}$ Angulo Íñiguez, Arquitectura mudéjar, p. 161; Guerrero Vega, "Construcción de la torre", pp. 703s y López Vargas-Machuca, "La irradiación”, p. 20.

${ }^{126}$ López Vargas-Machuca, El edificio medieval, p. 85 ve en Córdoba el origen de los temas jerezanos.

${ }^{127}$ Morales Martínez et al., Guía, p. 325.

${ }^{128}$ A.C.S., 1427; A.C.S., 1446, $14 \mathrm{v}^{\circ}-16$ y A.C.S., $1473,2 v^{\circ}$. 
vieja [...]" y el maestrescuela cien más por la "otra cámara en dicho torreón que está junto al Sagrario [Viejo...]" "129; es decir, en 1496 el mirador ya existía ${ }^{130}$. Teniendo en cuenta que el gran seísmo de 1356 derribó el remate del alminar ${ }^{131}$, podemos proponer que también destruiría lo más expuesto de la puerta del Perdón, que eran los tejaroces y sus empotramientos, sobre los que en siglo siguiente hicieron el mirador, pues el patio, a partir de 1433, se había convertido en un espacio muy animado. Es evidente que la construcción de la espadaña exigió en 1578 el refuerzo del conjunto y el derribo parcial de la tribuna, que también quedaría afectada por ruina de 1799 y las obras subsiguientes. Por cierto interesa señalar que el cuadrante solar que hay en uno de sus merlones, además de ser del siglo XVII ${ }^{132}$, no rememora uno andalusí, pues los de mezquitas son horizontales y con más de un gnomon ${ }^{133}$.

Volvamos a la obra almohade. En los arcos visibles del zaguán ("I20J" e "I21Js"), como ya he indicado, se advierten dos obras sucesivas, siendo la primera de ladrillo y con decoración propia (arquivolta lobulada, salmeres sencillos y alfices simples), mientras la segunda consistió en añadir otra, muy exuberante, corrigiendo las formas y dimensiones precedentes. Además, la puerta propiamente dicha presenta una reforma significativa ${ }^{134}$, pues cuando está cerrada se advierte que las mochetas contra las que entablan las hojas son tapiales recortados, con restos de los ladrillos que formaban el hueco [Figura 19]; por tanto se sucedieron en la puerta estas operaciones:

(1) hubo una puerta menor que la actual, cuyas hojas, si existieron, fueron más pequeñas;

(2) demolieron la primera versión del arco "I21Jn" para ampliar el espacio, eliminando casi por completo los ladrillos que encajonaban el tapial;

(3) reconstruyeron el arco "I21Jn", que pasó de los 2,90 $\mathrm{m}$ a los actuales 3,52, prolongando las mochetas hacia el sur para labrar el arco "I21 Js", finalmente

${ }^{129}$ A.C.S., $1496,43 v^{\text {o }}$; A.C.S., 1497,37 y A.C.S., 1498, 7.

${ }^{130}$ En 1513 no rentaba, pues lo usaban los mozos de coro (A.C.S., 1513, 213 y A.C.S., 1542-1560, 312).

${ }^{131}$ Antes de 1496 hubo seísmos en 1356, 1373, 1375, 1388, 1401, 1431, 1464 y 1494 (Gentil Gobantes, El riesgo sísmico, p. 187-192).

${ }^{132}$ Raya Román, "Los siete relojes", p. 143.

${ }^{133}$ Dorce Polo, "Sobre el cuadrante".

${ }^{134}$ Resumen de parte de la tesis doctoral de Jiménez Sancho, La Mezquita Mayor. 


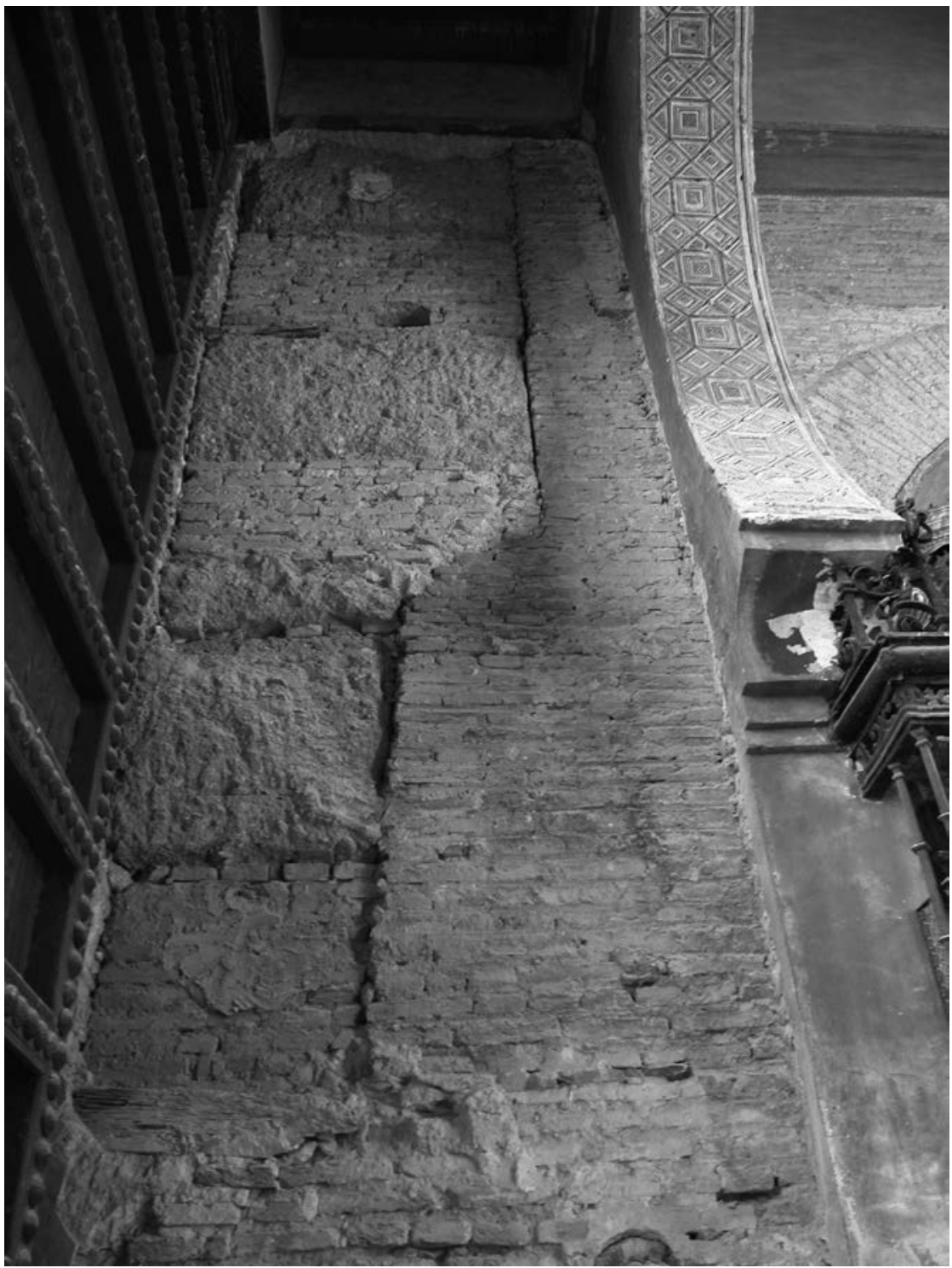

Figura 19. Desde los años setenta del XX, así se ve la mocheta del lado de levante de la puerta, apariencia que le quedó al muro de tapial una vez que se eliminó casi por completo el ladrillo que lo encofraba y las jambas de un arco menor (Foto del autor). 
(4) hicieron el friso de lazo, pues corresponde a las dimensiones de las hojas actuales, colocadas en este momento.

Estos dos tipos de cambios, el decorativo de los arcos y el estructural de la puerta, tienen paralelos en otras partes del edificio ${ }^{135}$, pues en la del Lagarto ("14A15"), adyacente a la torre, se excavó en 1996 un primer hueco ${ }^{136}$, de dos metros de anchura, ampliado hasta los 2,41 actuales, modificación vinculada a la construcción del alminar. También hay cambios decorativos en todos los arcos bien conservados, pero sobre todo en la puerta cegada en el centro de la fachada de la calle Placentines, consistente en dos trazados complementarios, que dan una idea de cómo quedaron decorados los huecos exteriores, pues el menor se ciñó al arco de ladrillo, mientras el mayor, un "arco de hojas", anuló el alfiz original ${ }^{137}$; el primero tiene en la clave un motivo existente en varios arcos del alminar y además arranca de un salmer añadido, distinto del pétreo anterior. Esta modificación permite relacionar el cambio decorativo con la torre, pues antes de 1888 sus bíforas tenían también una decoración superpuesta a la de ladrillo ${ }^{138}$. Podemos confirmar, por lo tanto, la existencia dos intervenciones generales, que modificaron la austera obra original del oratorio:

A. Ampliaciones de las dos puertas del edificio mejor conocidas, estando la del Lagarto relacionada con el alminar; en la del Perdón los extremos de las galerías adyacentes se reorganizaron.

B. En todos los elementos conservados tenemos una reforma decorativa, intensa y sistemática, ocultando las líneas tectónicas primigenias, ya fuesen de ladrillo o de piedra, bajo complejos y extensos acabados.

Por otra parte, están los datos cronísticos, que documentan tres etapas, siempre matizables en función de las traducciones disponibles:

I. De 1172 a 1182. Obras de nueva planta de la sala de oración.

II. De 1184 a 1188. Primera etapa de la torre, las murallas anexas y la $m \bar{\imath} d \bar{a}$.

III. De 1188 a 1198. Segunda etapa del alminar, ampliación o construcción del patio, mejoras generales y construcción de la Alcaicería.

\footnotetext{
${ }^{135}$ Estas demoliciones quizás tengan alguna relación con lo indicado en la nota 12.

${ }^{136}$ Tabales Rodríguez, "Investigaciones arqueológicas", p. 137.

${ }^{137}$ Aún se percibe bien su impronta, descubierta por Hernández Giménez en 1969.

138 Jiménez Martín, “Las yeserías”, p. 205.
} 
No es la primera vez que relaciono la cronología de ambas series, la relativa arqueológica y la absoluta cronística, y por ello, a medida que aumenta la información, he ido revisando las conclusiones ${ }^{139}$; en este momento creo que el cotejo de las dos lleva, sobre la base del oratorio de nueva planta (1172-1182), la intervención "A" a la segunda etapa (1184-1188) y la "B" a la tercera (1188-1198). Especialmente orientativas me parecen las palabras de la crónica cuando indica que en 1189 se ordenó "[...] que se reanudasen las obras del alminar y se reparase cualquier deterioro [localizado] en la aljama. Empezó a trabajar en el [alminar] el arquitecto 'Alī al-Gumārī y lo hizo utilizando ladrillos que eran [más adecuados para esta] construcción que la piedra citada y restauró lo que se había deteriorado en tres naves de la mezquita, la del este, la del oeste y la del sur, las reparó y las reforzó. Niveló la mezquita con gradas por el flanco oeste [...]"140, orientaciones que casualmente coinciden con las del patio.

En estas páginas ofrezco una restitución gráfica [Figura 20] de cómo fue la puerta en 1198, constituyéndose un modelo para el futuro. Las mezquitas almohades tienen, entre otras cualidades, la simetría axial como principio ordenador de sus espacios ya que, a partir del miḩrāb y el eje que orienta el rezo, se disponen de manera rígida y ortogonal soportes, naves, patio, o patios, y puertas. En varias ocasiones no lograron la deseada simetría, pues ampliaron mezquitas irregulares y con elementos dignos de ser conservados, pero en las nuevas, como Tinmal, Sevilla, Rabat, Marrakech (Qașba) y otras ${ }^{141}$, la regularidad fue norma. Lo interesante del caso sevillano es que, siendo muy tradicional en sus disposiciones, se constituyó como modelo para los siglos venideros, hasta alcanzar la época sa 'adí. Y esto es muy evidente en las puertas, pues entre las muchas que suelen tener por todo el contorno, descollaba, cuando existía, la enfrentada con el nicho de oración, pero, salvo por esto, destacaba poco, al contrario que en nuestro caso, donde la ordenación axial del conjunto, entre la alcazaba y la medina, la ubicación de la Alcaicería, pero sobre todo las formas arquitectónicas, hicieron que la del Perdón fuese la puerta mayor hasta el siglo XVI ${ }^{142}$. Por ello

${ }^{139}$ La última en Jiménez Martín, "La planta", p. 73.

${ }^{140}$ Roldán Castro, "De nuevo sobre la mezquita", p. 20

${ }^{141}$ Plantas en Ewert, "La mezquita de Mértola", p. 24.

${ }^{142}$ Cuando la visita de Felipe II, Juan de Malhara, organizador del evento, pretendió que accediera por la puerta del Perdón almohade (de Malhara, Recebimiento, $169 \mathrm{v}^{\circ}$ ), pero no lo consiguió. 


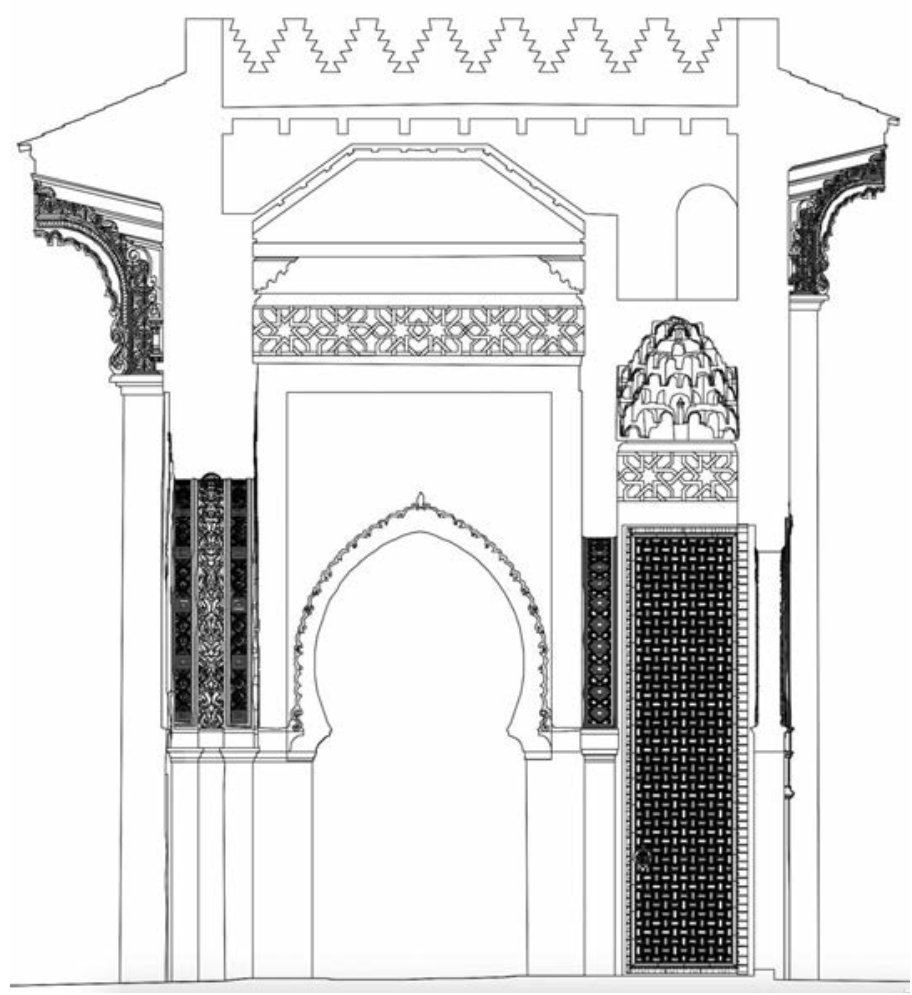

Figura 20. Restitución convencional de la sección de la puerta en su momento final almohade, mirando a poniente; muestra varias etapas (las almohades, el perfil del arco plateresco y el tejaroz de 1972) y varias suposiciones (la bóveda, la armadura y el tejaroz exterior (Datos y dibujo del autor).

sorprende que Fernández Puertas, en su exhaustivo y detallado repertorio de puertas ${ }^{143}$ no tomase en consideración la que, en primera instancia, más se parece a la nuestra, la de la aljama andalusí de Fez, una de las ciudades más citadas en su memorable trabajo; la misma ausencia se advierte en la memoria del proyecto del tejaroz que firmó Hernández el 7 de abril de $1971^{144}$, máxime cuando la portada de mezquita marroquí había sido publicada por su amigo Henri Terrasse en $1942^{145}$.

\footnotetext{
${ }^{143}$ Fernández Puertas, La fachada del palacio.

${ }^{144}$ A.G.A., 1971.

${ }^{145}$ Terrasse, La mosquée.
} 
La portada norte de la mezquita de los Andaluces [Figura 21] posee, además, un tejaroz notable, con 3,40 m de altura, cuya datación depende de la que otorguemos a las crujías septentrionales de las que forma parte; disponemos de dos crónicas meriníes, la de Ibn Ab̄̄ Zar ${ }^{6}$ al-Fāsī, fallecido hacia 1320, que relata cómo "En el mes de šawwāl (19 de abril a 17 de mayo 1208) salió el Príncipe de los Creyentes [Muhammad al-Nāșir, cuarto califa almohade] de Fez para Marrakech, después de haber ordenado la construcción del acueducto en la barriada de al-Andalus [...] Construyó también la puerta norte con la escalera, que sale a la plaza de la mezquita de los andaluces" ${ }^{146}$; la de Abū alHasan 'Alī al-Ŷaznā' $\overline{1}$, cuarenta años posterior ${ }^{147}$, dice "Il [Muḥammad al-Nāșir] ordonna de construire la grande porte du nord (précédée) des degrés et d'une largeur de vingt empans, d'une hauteur de vingt-sept. Le nombre des degrés était de quatorze. A la base de cette porte était une cloison grillagée en bois de cèdre percée de trois portes. Celle du milieu donnait sur un bassin de pierre jaune, dans lequel arrivait l'eau, amenée de l'Oued Mașmoûda et passant au pied de cette porte principale, a fin que les fidèles entrant nu-pieds s'y lavent. Au dessus de la porte il fit faire deux coupoles, l'une de plâtre sculpté du côte de l'intérieur de la Mosquée, l'autre de bois de cèdre, vers l'extérieur"148. Estos datos fueron interpretados por Terrasse así "Vue de l'intérieur, cette porte, avec ses quatre arcs disposés à trois niveaux différents, est fort belle ${ }^{149}$. Mais c'est de l'extérieur qu'elle apparaît dans toute sa majesté. Sa haute façade se dresse au bout d'une rue montante comme une apparition inattendue (Pl. XV). Sans doute — en dehors de deux colonnes à bases et chapiteaux de marbre qui supportent les hauts pilastres flanquant la porte ${ }^{150}$ _ nous n'avons plus rien du décor almohade. L'arc lobé et le décor des tympans datent manifestement de l'époque alaouite (Pl. XVI et XVII). L'auvent a été refait aux débuts du Protectorat"151, análisis que, a mi juicio, explica que ni Hernández Giménez ni Fernández-Puertas se interesaran por este ejemplar, que además muestra im-

${ }^{146} \mathrm{Ibn}$ Abī Zar`, Raw ḍ al-Qirțās, p. 454.

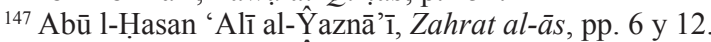

${ }^{148}$ Abū l-Ḥasan 'Alī al-Ŷaznā'̄i, Zahrat al-ās, pp. 169-171.

${ }^{149}$ Se refiere a la fachada al patio, $12 \mathrm{~m}$ al sur de la portada exterior.

${ }^{150}$ Distingue, en cuanto a cronología relativa, los capiteles del resto de la composición, como le ocurre al califal que hay en la bífora del mirador.

${ }^{151}$ Terrasse, La mosquée, p. 21. 


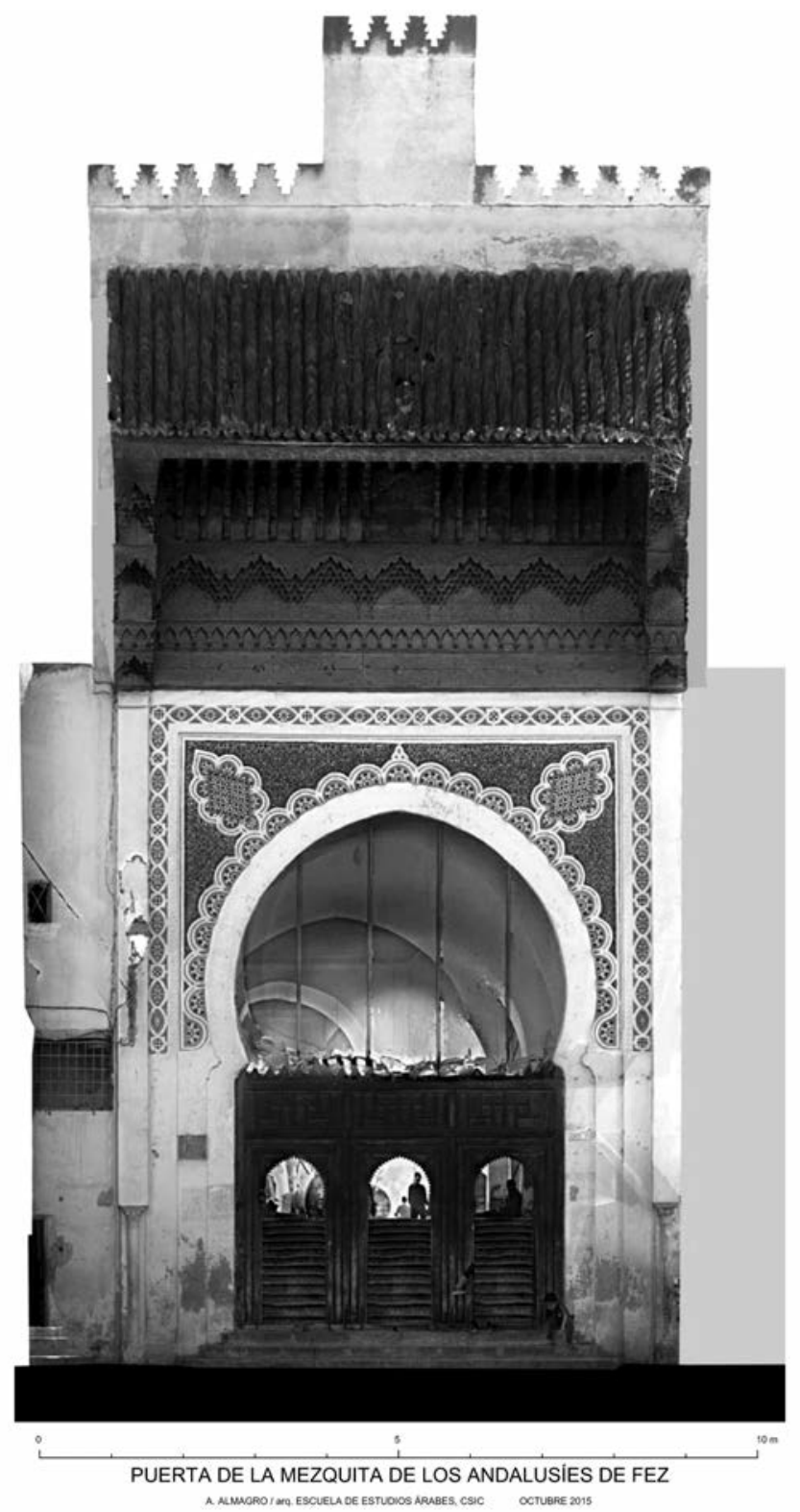

Figura 21. Ortofoto a escala del aspecto en 2015 de la portada principal de la mezquita de los Andaluces de la ciudad de Fez; por segunda vez en un siglo el tejaroz aparece en ruinas (Restitución fotogramétrica de A. Almagro, del proyecto

$$
\text { ARSA, HAR2014-53006-P). }
$$

Al-Qanțara XXXVIII 2, 2017, pp. 287-332 ISSN 0211-3589 doi: 10.3989/alqantara.2017.010 
portantes diferencias con nuestro caso, pues su parte principal y mayor mira a la qibla y preside el patio, llano y apaisado, mientras la portada fesí, de espaldas a la dirección del rezo y con un significativo descuadre, está fuera del ámbito religioso, mirando a la ciudad desde lo alto de una calle tan escalonada que en sesenta metros baja seis; sobre el tejaroz de Sevilla tenemos el mirador mudéjar, habitable, decorado y dotado de cinco amplias ventanas, mientras en Fez lo que vemos a contraluz es un cajón escueto, puramente estructural, como respaldo y contrapeso de la empinada cubierta del tejaroz, cuyo único hueco es una puertecita ubicada entre las tejas, que accede a un espacio de un metro de ancho, sobre el que hay un volumen ciego. Quizás el modelo de Fez, y de otras mezquitas, sea la puerta del Perdón de la catedral de Sevilla, pero divergen mucho, pues aquí la ubicación y formas de la puerta axial son del edificio primigenio, cuya altura incrementó una reforma cristiana, mientras en Fez la desviada puerta principal es el colofón de sucesivas ampliaciones del interior.

\section{Documentación de archivos.}

Archivo de la Catedral de Sevilla, Caja 12093, 22., 1363.

Archivo de la Catedral de Sevilla, Mesa Capitular 01477, 1411.

Archivo de la Catedral de Sevilla, Fábrica, 09705, 1427.

Archivo de la Catedral de Sevilla, Mesa Capitular, 08314, 1439.

Archivo de la Catedral de Sevilla, Fábrica, 09706, 1446.

Archivo de la Catedral de Sevilla, Fábrica, 09708-A, 1473.

Archivo de la Catedral de Sevilla, Secretaría, 07049, 1478 y 1479.

Archivo de la Catedral de Sevilla, Fábrica, 09349, 1496.

Archivo de la Catedral de Sevilla, Fábrica, 09350, 1497.

Archivo de la Catedral de Sevilla, Fábrica, 09351, 1498.

Archivo de la Catedral de Sevilla, Secretaría, 07053, 1498-1525.

Archivo de la Catedral de Sevilla, Fábrica, 09708-B, 1513.

Archivo de la Catedral de Sevilla, Secretaría, 09378, 1522.

Archivo de la Catedral de Sevilla, Mesa Capitular, 09163, 1542.

Archivo de la Catedral de Sevilla, Fábrica, 09709, 1542-1560.

Archivo de la Catedral de Sevilla, Fábrica, 09456, 1606.

Archivo de la Catedral de Sevilla, Liturgia, 04002, 1701-1719.

Archivo de la Catedral de Sevilla, Secretaría, 07137, 1707.

Archivo de la Catedral de Sevilla, Prebendados, 00008 B, 1796-1850.

Archivo de la Catedral de Sevilla, Secretaría, 07210, 1799. 
Archivo de la Catedral de Sevilla, Secretaría, 07229, 1818.

Archivo de la Catedral de Sevilla, Correspondencia 11195, 20, 1930.

Archivo General de la Administración, (3) 115 26/00386, 1944.

Archivo General de la Administración, (5) 14.2 32/17286, 1948.

Archivo General de la Administración, (3) 115 26/0016, 1971.

\section{Bibliografía}

Abū l-Ḥasan 'Alī al-Ŷaznā'̄, Zahrat el-as (La fleur de myrte) traitant de la fondation de la ville de Fès, trad. Alfred Bel, Argel, Jules Carbonel, 1923.

Almagro Gorbea, Antonio, "De mezquita a catedral. Una adaptación imposible" en La Piedra Postrera [Actas del] Simposium Internacional sobre la catedral de Sevilla en el contexto del gótico final (1) Ponencias, Sevilla, Taller Dereçeo, 2007, pp. 13-45.

Almagro Gorbea, Antonio et al., Atlas arquitectónico de la catedral de Sevilla, Granada, Cabildo Metropolitano, 2007.

Alonso Ruiz, Begoña y Jiménez Martín, Alfonso, La traça de la iglesia de Sevilla, Sevilla, Cabildo Metropolitano, 2009.

Álvarez Márquez, María del Carmen, El mundo del libro en la iglesia catedral de Sevilla en el siglo XVI, Sevilla, Diputación Provincial de Sevilla, 1992.

Amador de los Ríos y Serrano, José, Sevilla pintoresca, o descripción de sus más celebres monumentos artísticos [...], [Sevilla] Barcelona, [Francisco, Alvarez y Cía.] El Albir, 1844.

Angulo Íñiguez, Diego, Arquitectura mudéjar sevillana de los siglos XIII, XIVy $X V$, Sevilla, Universidad de Sevilla, 1932.

Aranda Campos, Antonio, "El templo parroquial de La Puebla del Río. Evolución arquitectónica de una iglesia fortificada a orillas del Guadalquivir" en La Puebla del Río: miscelánea histórica, Sevilla, Universidad de Sevilla, 2010, pp. 79-92.

Ballesteros Beretta, Antonio, Sevilla en el siglo XIII, [Madrid] Sevilla, [Juan Pérez Torres] Colegio Oficial de Aparejadores y Arquitectos Técnicos de Sevilla, [1913] 1978.

Balmelle, Catherine et al., La décor geómétrique de le mosaïque romaine. Répertoire graphique et descritif des compositions linéaires et isotropes, París, Picard, 1985.

Borrero Fernández, Mercedes, "Realidad económica y social de los vecinos de La Puebla del Rio en la Edad Media tardía” en La Puebla del Río: miscelánea histórica, Sevilla, Universidad de Sevilla, 2010, pp. 59-78.

Bravo Bernal, Ana María, El Sagrario, un problema y su historia. Estudio arquitectónico y documental de la capilla del Sagrario de la Catedral de Sevilla, Sevilla, Universidad de Sevilla, 2008.

Al-Qanțara XXXVIII 2, 2017, pp. 287-332 ISSN 0211-3589 doi: 10.3989/alqantara.2017.010 
Calvo Capilla, Susana, Las mezquitas de al-Andalus, Almería, Fundación Ibn Tufayl de Estudios Árabes, 2014.

Calvo Serraller, Francisco et al., Iconografía de Sevilla, 1790-1868, Madrid, Ediciones El Viso, 1991.

Ceán Bermúdez, Juan Agustín, Apéndice a la Descripción Artística de la Catedral de Sevilla, Sevilla, [Viuda de Hidalgo] Renacimiento, [1805] 1981.

Collantes de Terán Sánchez, Antonio, "De nuevo, sobre el pendón real de la Catedral", Archivo Hispalense, 96/291-293 (2013), pp. 197-214.

Cruz Isidoro, Fernando, Arquitectura sevillana del siglo XVII. Maestros mayores de la Catedral y del Concejo Hispalense, Sevilla, Universidad de Sevilla, 1997.

de Ariño, Francisco, Sucesos de Sevilla de 1592 a 1604, recogidos por Francisco de Ariño, vecino de la ciudad en el barrio de Triana, Sevilla, [Sociedad de Bibliófilos Andaluces] Ayuntamiento de Sevilla, [1873] 1993.

de Malhara, Juan, Recebimiento que hizo la muy noble y muy leal ciudad de Sevilla, a la C.R.M. del Rey D. Philipe. N.S., Sevilla, [Alonso Escribano] Fundación El Monte, [1570] 1998.

de Morgado, Alonso, Historia de Sevilla, en la qual se contienen svs antigvedades, grandezas [...], Sevilla, [Pefcioni, Andrea y Juan de León] Extramuros, 1587.

de Sigüenza Esteban, Francisco, Traslación de la imagen de Nuestra Señora de los Reyes y cuerpo de San Leandro y de los cuerpos reales a la Real Capilla de la Santa Iglesia de Sevilla, Sevilla, Fundación El Monte, [1579] 1996.

Dorce Polo, Carlos, "Sobre el cuadrante solar de Alfonso X el Sabio", Asclepio, 51/2 (1999), pp. 167-184.

Escudero Merchante, José María, La iglesia de San Martín de Tours de Sevilla. Historia y Descripción Artística, Sevilla, Imperial Archicofradía Sacramental de la Sagrada Lanzada, 1986.

Ewert, Christian, "La mezquita de Mértola (Portugal)", Cuadernos de la Alhambra, 9 (1973), pp. 3-36.

Ewert, Christian et al., Hispania antiqua. Denkmäler des Islam von den Anfägen bis zum 12. Jahrhundert, Mainz am Rhein, Philipp von Zabern, 1997.

Falcón Márquez, Teodoro, La capilla del Sagrario de la Catedral de Sevilla, Sevilla, Diputación Provincial, 1977.

Falcón Márquez, Teodoro, "Procesión con motivo del estreno de la iglesia del Sagrario. Documento pictórico del entorno de la catedral de Sevilla en 1662", Laboratorio de Arte, 121999 (2000), pp. 143-151.

Fernández Puertas, Antonio, La fachada del palacio de Comares (I) Situación, Función y Génesis, Granada, Patronato de la Alhambra, 1980.

Gentil Gobantes, Pilar, El riesgo sísmico en Sevilla, Sevilla, Universidad de Sevilla, 1989.

Gestoso y Pérez, José, Sevilla Monumental y Artística [...], 2, Sevilla, [Ayuntamiento de Sevilla] Monte de Piedad y Caja de Ahorros de Sevilla, [1890] 1984. 
Gómez de Terreros y Guardiola, María del Valle y Díaz Zamorano, María Asunción, "La restauración del Patio de los Naranjos de la catedral de Sevilla. Los proyectos de Félix Hernández Giménez" en Magna Hispalensis. Recuperación de la Aljama almohade, Sevilla, Cabildo Metropolitano, 2002, pp. 33-114.

González de León, Félix, Noticia artística histórica y curiosa de todos los edificios públicos, sagrados y profanos de esta muy noble, muy leal, muy heroica e invicta ciudad de Sevilla [...], Sevilla, [José Hidalgo y Compañía] Gráficas del Sur, [1844 y 1845] 1973.

González Gómez, Juan Miguel y Carrasco Terriza, Manuel Jesús, Catálogo Monumental de la Provincia de Huelva (I), Huelva, Universidad de Huelva, 1999.

González Jiménez, Manuel, La repoblación de la zona de Sevilla durante el siglo XIV. Estudio y documentación, Sevilla, Universidad de Sevilla, 1975.

González Jiménez, Manuel, Diplomatario andaluz de Alfonso X, Sevilla, El Monte, Caja de Huelva y Sevilla, 1991.

Guerrero Lovillo, José, Las Cantigas: estudio arqueológico de sus miniaturas, Madrid, Consejo Superior de Investigaciones Científicas, 1949.

Guerrero Vega, José María, "Construcción de la torre de la Atalaya de Jerez de la Frontera" en Sexto Congreso Nacional de Historia de la Construcción, Madrid, Sociedad Española de Historia de la Construcción, 2009, pp. 701-710.

Ibn Abī Zar', Raw d al-Qirțās, trad. Ambrosio Huici Miranda, Valencia, Nácher, 1964.

Ibn Șāḥib al-Ṣalā, al-Mann bi-l-imāma, trad. Ambrosio Huici Miranda, Valencia, Dario de Anubar, 1969.

Jiménez Martín, Alfonso, "Las yeserías de la Giralda", Andalucía Islámica. Textos y estudios, 2-3 (1981-82), pp. 195-206.

Jiménez Martín, Alfonso, "La qibla extraviada", Cuadernos de Madinat al-Zahra, 3 (1991), pp. 189-209.

Jiménez Martín, Alfonso, "Las fechas de las formas. Selección crítica de fuentes documentales para la cronología del edificio medieval" en La catedral gótica de Sevilla. Fundación y fábrica de la obra nueva, Sevilla, Universidad de Sevilla, 2006, pp. 15-113.

Jiménez Martín, Alfonso, "La planta de la mezquita almohade de Sevilla", Boletín de la Real Academia de Bellas Artes de Nuestra Señora de las Angustias de Granada, 12 (2007), pp. 50-87.

Jiménez Martín, Alfonso, Anatomía de la catedral de Sevilla, Sevilla, Diputación Provincial de Sevilla, 2013.

Jiménez Martín, Alfonso y Cabeza Méndez, José María, Tvrris Fortissima. Documentos sobre la construcción, acrecentamiento y restauración de la Giralda, Sevilla, Colegio Oficial de Aparejadores y Arquitectos Técnicos de Sevilla, 1988.

Jiménez Martín, Alfonso y Pérez Peñaranda, Isabel, Cartografía de la Montaña Hueca. Notas sobre los planos históricos de la catedral de Sevilla, Sevilla, Cabildo Metropolitano, 1997. 
Jiménez Sancho, Álvaro, La Mezquita Mayor almohade de Sevilla. Análisis arqueológico de su construcción. Tesis doctoral inédita, Universidad de Sevilla, Departamento de Prehistoria y Arqueología, 2016.

Jordano Barbudo, María Ángeles, "La puerta del Perdón de la mezquita-catedral de Córdoba", Laboratorio de Arte, 28 (2016), pp. 15-40.

Kirschberg Schenck, Deborah, Catálogo de los Papeles del Mayordomazgo VI (1475-1488), Sevilla, Ayuntamiento de Sevilla, 2013.

Laguna Paúl, Teresa, "Miguel Perrin en las portadas de la Catedral de Sevilla. Maestre Miguel o la fortuna artística de un imaginero de barro" en Archivos de la Iglesia de Sevilla. Homenaje al archivero D. Pedro Rubio Merino, Córdoba, Caja Sur, 2006, pp. 723-752.

Laguna Paúl, Teresa, "Miguel Perrín, imaginero de barro al servicio de la Catedral de Sevilla" en Nuevas perspectivas criticas sobre historia de la escultura sevillana, Sevilla, Junta de Andalucía, 2007, pp. 81-105.

Laguna Paúl, Teresa, "Llegada y primeras obras de Miguel Perrin en la catedral de Sevilla: el programa escultórico de la reconstrucción del cimborrio de Juan Gil de Hontañón”, Laboratorio de Arte, 24 (2012), pp. 137-162.

Laguna Paúl, Teresa, "Marco arquitectónico y retórica visual en barro en la catedral de Sevilla" en Begoña Alonso Ruiz y Juan Clemente Rodríguez Estévez (coord.), 1514: Arquitectos tardogóticos en la encrucijada, Sevilla Universidades de Cantabria y Sevilla, 2016, pp. 31-48.

López Pertíñez, María del Carmen, La carpintería en la arquitectura nazarí, Granada, Fundación Rodríguez Acosta, 2006.

López Vargas-Machuca, Fernando, El edificio medieval de San Dionisio de Jerez de la Frontera, Madrid, Peripecia Libros, 2014.

López Vargas-Machuca, Fernando, "La irradiación del gótico-mudéjar jerezano. El Divino Salvador de Vejer de la Frontera" en Nuevas aportaciones a la Historia del Arte en Jerez de la Frontera y su entorno, Cádiz, Universidad de Cádiz, 2016, pp. 17-48.

Luna Fernández-Aramburu, Rocio y Serrano Barberán, Concepción, Planos y dibujos del archivo de la catedral de Sevilla (Siglos XVI-XX), Sevilla, Diputación Provincial de Sevilla, 1986.

Martínez Antuña, Melchor, Sevilla y sus monumentos árabes. Artículos publicados en "Religión y Cultura", San Lorenzo de El Escorial, Imprenta del Monasterio, 1930.

Martínez Núñez, María Antonia, "Yeserías epigrafiadas del Castillo de Santa Catalina (Jaén)", Arqueología y territorio medieval, 9 (2002), pp. 165-179.

Martínez Núñez, María Antonia, "Ideología y epigrafia almohades" en Almohades: problemas y perspectivas (I), Madrid, Consejo Superior de Investigaciones Científicas, 2005, pp. 5-52.

Martínez Núñez, María Antonia, "El Corán en los textos epigráficos andalusíes" en El Corán ayer y hoy. Perspectivas actuales sobre el Islam. Es- 
tudios en honor al profesor Julio Cortés, Córdoba, Berenice, 2008, pp. 125-144.

Martínez Núñez, María Antonia, "Hiisba y ŷihād en época almohade: el testimonio epigráfico" en Cristãos contra muçulmanos na Idade Média peninsular: bases ideológicas e dou Cristianos contra musulmanes en la Edad Media peninsular: bases ideológicas y doctrinales de una confrontación: (siglos X-XIV), Madrid, Universidad Autónoma de Madrid, 2015, pp. 115-138.

Maslow, Boris, Les Mosquées de Fès et du Nord du Maroc, París, Les Éditions d'Art et d'Histoire, 1937.

Matute y Gaviria, Justino, Anales eclesiásticos y seculares de la muy noble y muy leal ciudad de Sevilla [...], Sevilla, [Imp. de E. Rasco] Ediciones Guadalquivir, [1887] 1997.

Morales Martínez, Alfredo José et al., Guía Artística de Sevilla y su Provincia, Sevilla, Diputación Provincial de Sevilla, 1981.

Navarro Palazón, Julio y Jiménez Castillo, Pedro, Casas y palacios de al-Andalus. Siglos XII-XIII, Barcelona y Granada, El Legado Andalusí y Lunwerg Editores, 1995.

Navarro Palazón, Julio y Jiménez Castillo, Pedro, Siyasa. Estudio arqueológico del despoblado andalusí (ss. XI-XIII), Granada, El legado andalusí 2007.

Nickson, Tom, "'Sovereignty belongs to God': Text, Ornament and Magic in Islamic and Christian Seville", Art History, 38/5 (2015), pp. 814-837.

Nieto Cumplido, Manuel, La Catedral de Córdoba, Córdoba, CajaSur, 1998.

Nuere Matauco, Enrique, La carpintería de armar española, Madrid, Ministerio de Cultura, 1989.

Ortiz de Zúñiga, Diego, Annales eclesiásticos y seculares de la muy noble, y muy leal Civdad de Sevilla [...], 2, [Madrid] Sevilla, [Imprenta Real], Guadalquivir, [1795] 1988.

Ortiz de Zúñiga, Diego, Annales eclesiásticos y seculares de la muy noble, y muy leal Civdad de Sevilla [...], 3, [Madrid] Sevilla, [Imprenta Real], Guadalquivir [1796] 1988.

Pérez-Embid Wamba, Javier, Culto funerario y registro necrológico de la Catedral de Sevilla (siglos XIII-XV), Madrid, Dykinson, 2015.

Quiles García, Fernando, Teatro de la Gloria. El universo artístico de la Catedral de Sevilla en el Barroco, Sevilla, Diputación Provincial, 2007.

Raya Román, José María, "Los siete relojes de la catedral de Santa María de la Sede de Sevilla" en XXI edición del Avla Hernán Rviz. "Las horas, las palabras y el Facistol" (1), Taller Dereçeo, 2014, pp. 133-153.

Recio Mir, Álvaro, "La reforma y restauración de la Puerta del Perdón de la Catedral de Sevilla de 1578-1580", Laboratorio de Arte, 9 (1996), pp. 73-88.

Rodríguez Barberán, Francisco Javier, "Sevilla en tiempos de Richard Ford. Una mirada singular sobre la ciudad y sus gentes" en La Sevilla de Richard Ford (1830-1833), Sevilla, Fundación El Monte, 2007, pp. 111-145. 
Roldán Castro, Fátima, “De nuevo sobre la mezquita aljama almohade de Sevilla: la versión del cronista cortesano Ibn Șāhị al-Șalā” en Magna Hispalensis. Recuperación de la Aljama almohade, Sevilla, Cabildo Metropolitano, 2002, pp. 13-22.

Salem, 'Abd al-'Aziz, "La Puerta del Perdón en la gran mezquita de la Alcazaba almohade de Sevilla", Al-Andalus, 30/1, (1978), pp. 201-207.

Serrera Contreras, José Miguel, "Pintura y pintores del XVI en la catedral de Sevilla" en La catedral de Sevilla, Sevilla, Guadalquivir, 1984, pp. 353-399.

Serrera Contreras, José Miguel, Oliver Carlos, Alberto y Portús Pérez, Javier, Iconografia de Sevilla. 1650-1790, Madrid, El Viso, 1989.

Tabales Rodríguez, Miguel Ángel, Huarte, R., García, E. y Romo, A., "Investigaciones arqueológicas en la acera de levante de la catedral de Sevilla" en Magna Hispalensis. Recuperación de la Aljama almohade, Sevilla, Cabildo Metropolitano, 2002, pp. 115-168.

Terrasse, Henri, La mosquée des Andalous a Fès, París, Les Éditios d'Art et d'Histoire, 1942.

Torres Balbás, Leopoldo, Artes almorávide y almohade, Madrid, Consejo Superior de Investigaciones Científicas, 1955.

Uceda Valiente, Julia et al., Sevilla artística y monumental, 1857-1880. Fotografias de J. Laurent, Madrid, MAPFRE Ministerio de Cultura, 2008.

Valdivieso González, Enrique, Historia de la Pintura sevillana. Siglos XIII al XX, Sevilla, Guadalquivir, 1992.

Valencia Rodríguez, Rafael, “Aldabón de la Puerta del Perdón” en Averroes y su época. Catálogo de la exposición, Sevilla, Fundación El Monte, 1998, pp. 146-147.

Valencia Rodríguez, Rafael, “Aldabón de la puerta del Perdón” en Metropolis Totius Hispaniae. 750 Aniversario de la Incorporación de Sevilla a la Corona Castellana, Sevilla, Ayuntamiento de Sevilla, 1998, pp. 196-197.

Velázquez y Sánchez, José, Anales de Sevilla de 1800 a 1850, Sevilla, [Imprenta y Librería de Hijos de Fe] Ayuntamiento de Sevilla, [1872] 1994.

Vera Reina, Manuel, "La mida de la aljama almohade de Sevilla" en El último siglo de la Sevilla islámica (1147-1248), Sevilla, Universidad de Sevilla, 1995, pp. 161-166.

Yáñez Polo, Miguel Ángel, V.M. Casajus, introductor de la Litografía y el Daguerrotipo en Sevilla. Incluye las 13 primeras litografías realizadas en Sevilla, Sevilla, Sociedad de Historia de la Fotografía Española, 1987.

Yáñez Polo, Miguel Ángel y Mesa García, José Antonio, Sevilla recuperada. 160 años de Historia a través de la Fotografía. Selección antológica de la Fototeca Hispalense, Sevilla, Diario de Sevilla, 2000.

Recibido: $23 / 02 / 2017$

Aceptado: 18/12/2017

Al-Qantara XXXVIII 2, 2017, pp. 287-332 ISSN 0211-3589 doi: 10.3989/alqantara.2017.010 